Alma Mater Studiorum - Università di Bologna DEPARTMENT OF ECONOMICS

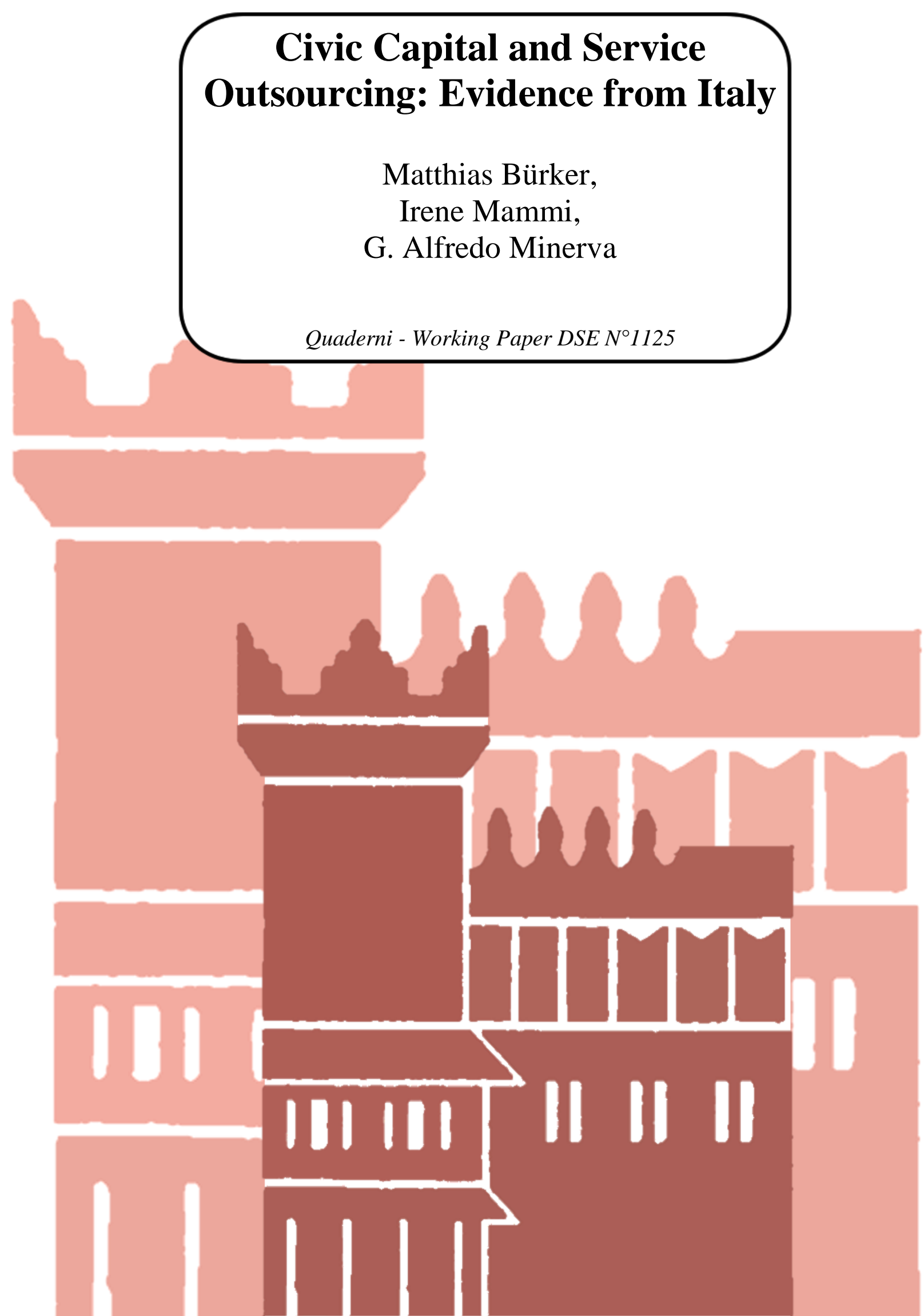




\title{
Civic Capital and Service Outsourcing: Evidence from
}

\author{
Italy * \\ Matthias Bürker $†$ Irene Mammi $;$ G. Alfredo Minerva ${ }^{\S}$
}

November 3, 2018

\begin{abstract}
This paper studies whether civic capital (those persistent shared beliefs and values that help a group overcome the free rider problem in the pursuit of socially valuable activities) acts an effective restraint against opportunistic behavior in transactions by looking at the firm-level degree of service outsourcing in Italy. Our results show that firms tend to outsource more services in areas where civic capital is higher. We claim that the rise in the propensity to engage in transactions with outside service suppliers stems from the decrease in opportunism between the parties involved. We consider a dynamic specification which allows to disentangle state dependence of service outsourcing from firm-level heterogeneity, and we use historical instruments to address the potential endogeneity of civic capital.
\end{abstract}

JEL Classification: A13, L20, L24, R12

Keywords: Civic Capital; Purchased Service Intensity; Vertical Integration; Outsourcing.

*We thank for their comments Erich Battistin, Marco Casari, Maurizio Caserta, Guido de Blasio, Stefano Federico, Sauro Mocetti, Sandro Montresor, Henry Overman, Giovanni Peri, Patrick Sevestre, Chad Syverson, Jeffrey Wooldridge, participants to the 51st Annual Meeting of the Italian Economic Association in Catania, the 4th Italian Congress of Econometrics and Empirical Economics in Pisa, the 53rd Annual Congress of the European Regional Science Association in Palermo.

${ }^{\dagger}$ Banque de France, Paris, France. E-mail: matthias.burker@banque-france.fr.

$\ddagger$ University Ca’ Foscari of Venice, Italy. E-mail: irene.mammi@unive.it.

$\S$ Corresponding author. University of Bologna and Centro Studi Luca d'Agliano, Italy. E-mail: ga.minerva@unibo.it. 


\section{Non-technical summary}

Understanding the determinants of firm boundaries is a fundamental concern in economics. Over the last 40 years, important theoretical contributions have highlighted the role of incomplete contracts and transaction costs for the firms' decision of whether to produce a given input in-house or to purchase it from external suppliers. In a nutshell, these theories sustain that if contracts are not fully enforceable by third parties and unforeseen contingencies occur, agents have an incentive to renege on initial agreements and behave opportunistically, something which reduces the efficacy of written agreements and creates contracting costs. Between in-house production and external sourcing, firms are expected to choose the form of production that minimizes these costs.

The present paper analyzes the role of informal institutions, proxied by the stock of local civic capital, for the firms' organization of production. Civic capital is defined as those persistent shared beliefs and values that help a group overcome the free rider problem in the pursuit of socially valuable activities The importance of civic capital for the firm's makeor-buy decision resides in the fact that the underlying civic values and beliefs attenuate individual opportunistic behavior. Since the likelihood of opportunism decreases with the stock of civic capital, we expect the incidence of contractual hazards in economic transactions to be lower in more civic areas. As a consequence, the organization of production should vary with the stock of civic capital characterizing the area where it is located. More precisely, contractual hazards are more easily dealt with in integrated production processeses. Consequently, outsourcing should be lower in areas where civic capital is low (and opportunism is high) and more pronounced where civic capital abounds.

Using Italian firm level data, this paper tests whether the decision to outsource the production of service inputs is sensitive to the stock of civic capital of the province where the firm is located. Service transactions are well suited to our task. Contracts governing service transactions tend to be highly incomplete, as services are afflicted by measurement and hold-up problems as well as hazards related to asymmetric information between provider and client. Moreover, services are predominantly acquired on the local market which makes the effect of local civic capital on service outsourcing more straightforward to identify. The 
empirical results confirm that firms' intensity to purchase services from external providers increases with the stock of provincial civic capital. 


\section{Introduction}

Understanding the determinants of firm boundaries is a fundamental concern in economics. Starting with Coase (1937) and Williamson (1975), 1979), important theoretical contributions have highlighted the role of incomplete contracts and transaction costs for the firms' decision of whether to produce a given input in-house or to purchase it from external suppliers. When contracts are not fully enforceable by third parties and unforeseen contingencies occur, agents have an incentive to behave opportunistically on initial agreements, thus reducing the efficacy of written agreements and creating contracting costs. Between in-house production and external sourcing, firms are expected to choose the form of production that minimizes costs, taking duly into account transaction costs.

At the same time, a well developed literature documents that civic capital or societal trust have far reaching implications for economic outcomes in general (Putnam, 1993; Guiso et al., 2011; Algan and Cahud, 2014; Tabellini, 2010) and the behavior of firms in particular (Bloom et al., 2012). The key merit of the underlying values and beliefs that account for the stock of civic capital is that they attenuate narrow-minded self interested behavior. The propensity of individuals to engage in opportunistic behavior is thus lower in areas where civic values are more widespread.

In this paper, we combine the key insights from these two strands of literature and test empirically whether civic capital alters the boundaries of the firm: if the degree of opportunism decreases with the stock of civic capital, we expect the incidence of contractual hazards to be lower in more civic areas. As a consequence, the firm organization of production should vary with the stock of civic capital characterizing the area where it is located. More precisely, according to the transaction cost literature (Williamson, 1975, 1985), contractual hazards are more easily dealt with in integrated production processes. Consequently, others things equal, we should observe less outsourcing in areas where civic capital is low (as the propensity to behave opportunistically is higher) and more outsourcing where civic values are widespread.

Employing a large Italian firm-level data set, we investigate the relationship between the firms' degree of service outsourcing and the stock of civic capital in the province where the 
firm is located. The choice of using services rather than raw material inputs is dictated by several reasons. First, the transactions involving service purchases are particularly sensitive to contractual incompleteness, because they tend to be afflicted by measurement and holdup problems, and are often plagued by asymmetric information. This makes them a suitable input to look at for our purposes. Second, services are predominantly purchased in the local market (Schwartz, 1993; Ono, 2003; Merino and Rodrand, 2007). This makes the effect of local civic capital on service outsourcing more straightforward to identify, as both the buyer and the provider tend to be located in the same area, and hence they operate surrounded by the same level of civicness.

Our empirical results show that the stock of civic capital in a given province influences firm-level intensity to purchase services from external providers. In particular, we find that firms located in more civic provinces outsource on average more services. The results are robust against the inclusion of relevant firm-level and provincial controls, such as the quality of formal contracting institutions. Our empirical strategy carefully addresses concerns related to omitted variables and unobserved heterogeneity. In fact, we consider a dynamic specification which allows to disentangle state dependence of service outsourcing from firmlevel heterogeneity, while retaining the identification of time-invariant regressors, and we estimate it by System GMM (Blundell and Bond, 1998). We think this is a key aspect of our paper, since cross-sectional analyses dealing with an inherently dynamic phenomenon such as firm organizational structure may suffer from various sources of misspecification. At the same time, System GMM provides a set up where the effect of a time-invariant variable such as civic capital can still be identified. To the best of our knowledge, this article is the first to look at the relationship between firm organizational structure and, broadly defined, institutional setting by means of a fully-fledged dynamic model 1 We also rely on some historical excluded instruments and we document that the effect is unlikely to be driven by measurement error or reversed causation. Our results prove that informal institutions such as civic values and beliefs determine the boundaries of the firm. The fact that civic

\footnotetext{
${ }^{1}$ Papers based on cross-sectional analyses in this literature are Acemoglu et al. (2009), Bloom et al. (2012), and Macchiavello (2012). See below for more discussion about them.
} 
capital increases service outsourcing of firms strongly suggest that societal values and beliefs reduce the propensity of the parties involved in a transaction to defect. In this way, our analysis confirms Williamson's hypothesis that "societal culture" can improve the efficacy of contracts by reducing opportunism (Williamson, 1993).

Our paper contributes to the literature analyzing the institutional determinants of vertical integration. We find a direct and positive effect of the institutional setting on outsourcing: civic capital shapes firms' organization of production even after controlling for key aspects of institutional quality, such as the efficiency of the judiciary and the level of financial development. This result complements the findings of Acemoglu et al. (2009) and Macchiavello (2012), who show that the relationship between institutional development (contracting costs, financial development) and the firms' decision to vertically integrate is knotty. Acemoglu et al. (2009) find that the quality of contracting institutions has no direct effect on the degree of vertical integration. However, contracting institutions matter once industry heterogeneity is taken into account, since the efficiency of the judiciary brings more vertical integration in industries that are more capital-intensive. They also find greater vertical integration in countries that have both greater contracting costs and greater financial development. Macchiavello (2012) analyzes the interaction between industrial structure (in particular the industry's firm size distribution), financial development and vertical integration. For manufacturing industries, he shows that the degree of vertical integration decreases with financial development in industries where small firms are important. We stress that while these papers focus on the role of formal institutions, and find basically no evidence of a direct effect on vertical integration, in our paper we investigate the role of an informal institution such as civic capital, and find compelling evidence of a direct effect. Another peculiarity of our approach is the analysis of the sourcing decision of a specific input such as services (while these papers look at other, more general, measures of vertical integration).

Next, our paper is also related to the literature looking at the determinants of service outsourcing. Several factors that influence the propensity of firms to purchase services from external providers have been identified, ranging from labor cost savings Abraham and Tavlor, 1996), ICT investment (Abramovsky and Griffith, 2006), firm size (Abraham and Tavlor, 
1996; Merino and Rodrand, 2007), demand fluctuations (Abraham and Taylor, 1996), market share (Galdon-Sanchez et al., 2015) to the characteristics of the local market, in particular its size (Ono, 2007). None of these studies however focuses on how cultural traits, such as those embedded in civicness, affects service outsourcing.

Finally, our results complement the findings of Bloom et al. (2012) and Bürker and Minerva (2014) on the relationship between trust and civic capital and the size of private organizations. The fact that civic capital increases service outsourcing could bring a reduction in size, because the firm sources to external suppliers some activities. This notwithstanding, results in Bloom et al. (2012) and Bürker and Minerva (2014) show that there are other mechanisms at work that ensure that the total effect of civic capital on average size is still positive.

The remainder of the paper is organized as follows. The next section provides the conceptual framework and derives some testable implications. Section 3 describes the data and the variables employed. In section 4 we lay out the estimation strategy while section 5 describes the empirical results. In section [6 we employ historical instruments to address endogeneity concerns. Section 7 draws some conclusions.

\section{Civic capital and service outsourcing: conceptual framework}

For most economic transactions, it is virtually impossible to set up written agreements that specify contingencies for all possible future states. Rather, contracts are often incomplete and their enforceability by third parties is limited, something which gives the contracting parties an opportunity to renege on initial agreements and, as a consequence, undermines the efficacy of contracts. The fact that incomplete contracts involve contractual hazards ex-post is a direct consequence of opportunistic behavior on the part of the agents involved in the transaction. More generally, the transaction cost literature (Williamson, 1975, 1985) states that opportunism is a necessary condition for the emergence of contractual hazards. If opportunistic behavior, defined as "self-interest seeking with guile" (Williamson, 1996), 
were absent the efficacy of contracts would be guaranteed even if the underlying agreement was not enforceable by third parties. In such a setting, it would be sufficient to specify automatic adaptation clauses that apply when the conditions require an update of the written agreement.

In this study, we consider a specific case of how variations in opportunistic behavior shape the efficacy of contracts. We analyze how the firm decision to outsource or not services varies with the degree of opportunistic behavior characterizing the environment in which the transaction takes place. Studying the sourcing decision of services, rather than material inputs, has two advantages. First, we argue that the incidence of contract incompleteness is particularly strong in service transactions. As services are intangible and often non-standardized, the responsibilities and duties for each contracting party are hard to define and penalties for defection difficult to specify. Moreover, service transactions are likely to be afflicted by hold-up problems if the provider has to acquire specific physical or human capital to meet the needs of the client. Similarly, it might be that the client has to align its work setting in order to allow the provision of the service or to assist effectively the provider (DeBandt, 1996). Contractual frictions further increase due to measurement difficulties. As services lack well-defined technical standards it is generally difficult to measure quality or simply to compare it across different suppliers. Therefore, it is cumbersome to write a contract that specifies ex-ante clauses for each possible contingency that might emerge during the course of the contractual relationship. Rather, the contract that governs a service transaction is likely to be incomplete and requires ex-post adaptation to unforeseen contingencies.

The second advantage of studying transactions involving services resides in their limited tradability. This is an important aspect, as our variable of interest is civic capital, an inverse measure of the opportunistic attitude that characterizes the environment in which a transaction takes place. Hence, the effect is accurately identified when both transacting partners are located in the same area. In the case of service transactions this condition is likely to be fulfilled. The degree of spatial proximity between clients and providers is high for services such as repairing and maintenance, cleaning, or security that require repeated 
personal interaction between the client and the provider (DeBandt, 1996) 22 Even when the headquarters of the provider are located far from the client, the workers directly involved in the provision of the service have to reside close to the buyer 3 Differently from services, raw materials are more tradable, and hence the supplier's location can be far away from the buyer's. The assignment of an appropriate level of opportunism is puzzling in the case of raw materials transactions, and hence they constitute a less suitable object of analysis.

We associate the degree of opportunism in a given area to the stock of civic capital in the province where the firm is located. There are good reasons to believe that civic capital is a good proxy for the behavioral traits that inform about opportunistic behavior in economic transactions. Civic capital is defined as "those persistent shared beliefs and values that help a group overcome the free rider problem in the pursuit of socially valuable activities" (Guiso et al., 2011). Put differently, it captures all those societal values and beliefs that mitigate the free-rider problem, a genuine form of opportunistic behavior. Therefore, we conjecture that the stock of civic capital increases the efficacy of contracts as agents have a lower probability to defect. The concept of civic capital comes close to what Williamson terms "societal culture". He emphasizes that societal culture increases the efficacy of contracts, and hence shapes the organization of production, as it limits the incidence of opportunistic behavior (Williamson, 1996). 4

What are the implications of the reduction in contracting costs brought about by civic

\footnotetext{
${ }^{2}$ According to the Survey of Industrial and Service firms, conducted by the Bank of Italy in 2007, 2/3 of Italian firms purchase services exclusively from providers that are located in the same region. Even if we work with a smaller geographic partition (on average there are 5 provinces per region) this evidence confirms that service tradability is limited.

${ }^{3}$ For example, think to cleaning workers employed by a large service firm. The headquarters of the service firm may be located everywhere in Italy, but the workers directly hired to perform the daily cleaning operations should reside close to buyer.

${ }^{4}$ Relational contracts too have been found to affect the firms' integration decision (Baker et al., 2002), but they operate differently from civic capital. Relational contracts are sustained by the value of future relationships; that is, agents have a material interest not to renege on contractual agreements even if they are not enforceable by third parties. In contrast, the behavioral traits underlying civic capital deviate from strict self-interested behavior. Here, it is a given set of societal values and beliefs that attenuate opportunism and hence ensure cooperation, even if the transaction is not going to be repeated in the future.
} 
capital for the firms' intensity of service outsourcing? Transaction costs economics posits that if contractual hazards are acute provision is more efficiently achieved within firms, as its hierarchical structure is better able to solve disputes that may arise during the course of production. On the other hand, if contractual difficulties are small a product is efficiently provided by an independent supplier and then exchanged through a market transaction. The empirical literature has confirmed this prediction. Products that are complex and afflicted by hold-up are produced by integrated firms (Lafontaine and Slade, 2007).

Based on these insights, we aim at testing the following hypothesis: firms located in areas with low endowments of civic capital acquire less services from external suppliers. In these locations, opportunism is pervasive, and firms tend to rely more on the internalization of service provision. Conversely, where civic capital abounds transaction costs are lower, as agents have a lower propensity to renege on initial agreements and behave opportunistically. In this case, relatively more transactions concerning services are realized through arm's length relationships, so we should observe greater service outsourcing.

\section{Data and variables}

\subsection{Firm-level variables}

The primary source of information is AIDA, a firm-level dataset administered by the Bureau van Dijk. AIDA is a commercial dataset which provides information on balance sheets and profit and loss statements for hundreds of thousands of Italian businesses. From this dataset we extract information on a number of variables including value added, sales, the number of workers, total tangible fixed assets, service purchases, firm age. We also retain information about firms' geographic localization and industry. An important advantage of the AIDA dataset is that it includes firms operating in all industries. This implies that our results apply to the whole spectrum of economic activity 5

\footnotetext{
${ }^{5}$ The only industries that we exclude are: Public administration (NACE rev 1.1. code 75), Education (80), Health and social services (85), Unions, political parties and other organizations (91), Private households $(95,96,97)$ and Extraterritorial organizations (99).
} 
Analyzing service outsourcing with information collected at the firm-level rather than at the plant-level might be inaccurate if a firm runs multiple establishments. However, to the extent that decisions on service outsourcing are taken at the central firm headquarters, and are not decentralized to individual plants, there is no error due to firm-level aggregation. Under centralization, the degree of outsourcing of all the plants belonging to a given firm will be decided by the managers located at the central office and, according to our framework, it will be affected by the level of civic capital of the central office's province. Moreover, if sourcing decisions are made at individual plants the use of firm-level data is still adequate as long as plants and headquarters are located in the same province, since the different units are influenced by the same level of provincial civic spirit. The only case where firm-level data are problematic is when the decision to outsource services is decentralized at the plant level and plants are located outside of the province of the firm headquarters 6

The degree of service outsourcing at the firm-level is measured as follows. The item dedicated to services in the profit and loss statement informs about the total expenditures paid by the firm for external service provision.7 Since items recorded in the income statement are collected for accounting purposes, the purchase of specific services is not singled out, and we have only information on the total amount of purchased services. Service purchases are then divided by the total amount of sales in order to retrieve a measure of service outsourcing, that we call Purchased Service Intensity (PSI hereafter). This measure of service outsourcing has been employed before in the literature (Abramovsky and Griffith, 2006; Görg and Hanley, 2011). PSI contributes to value added over sales, which is a standard measure of the overall degree of vertical integration 8 The ratio of value added over sales captures how much of a firm's production is carried out within the firm boundaries. Leaving aside the variation in inventories to simplify notation, value added can be written as

$$
V A=\text { Sales }- \text { Services }- \text { Material Inputs - Other non-financial non-labor costs }
$$

\footnotetext{
${ }^{6}$ We are not the first to employ firm-level data to investigate the determinants of outsourcing. See Li and Lu (2009) for a paper about input outsourcing in China and Merino and Rodrand (2007) who analyze service outsourcing of Spanish firms.

${ }^{7}$ In Appendix A we give a detailect description of the kind of services that enter this item.

${ }^{8}$ The classical reference is Adelman (1955), and a more recent application is Macchiavello (2012).
} 
and then, dividing by sales, we get

$$
\frac{V A}{\text { Sales }}=1-P S I-P I I-\frac{\text { Other non-financial non-labor costs }}{\text { Sales }}
$$

where PII is Purchased (Material) Inputs Intensity. Consequently, the firm overall degree of vertical integration, measured by value added over sales, can be decomposed in three parts: PSI, which measures the contribution of the purchase of services on the market to the firm's degree of integration; PII, which measures the contribution of the purchase of material inputs on the market to the firm's degree of integration; a residual term, which is related to the decision to purchase on the market other types of inputs. In this paper we focus on the effect that civic capital exerts on firm-level vertical integration through the purchase of services. For completeness, we are also going to assess the effect of civic capital on the overall degree of vertical integration (value added over sales).

After removing outliers and observations with abnormal values, we end up with a sample consisting of more than 300,000 firms and almost 900,000 observations spanning the years 2001-2007.9 In Table 1 there are descriptive statistics. On average, the amount of purchased services equals $18.4 \%$ of firm sales, while the median value of PSI is slightly larger (20.1\%). Figure 1 shows average PSI across provinces. Overall, the pattern suggests that there is substantial geographic variation in business service outsourcing. Firms located in Northern Italy outsource more services than businesses in the South of the country. If we look at the four largest metropolitan areas of the country (Rome, Milan, Naples and Turin) average PSI of firms in the provinces of Rome (18.9\%), Milan (22.6\%), and Turin (21.1\%) is higher than the nationwide average. This is in line with Ono (2007) who finds that agglomeration economies favor service outsourcing of firms. An interesting exception in this regard is the province of Naples. The average PSI of firms located in this province equals $12.7 \%$, which is a value substantially lower than in other agglomerated areas and in Italy as a whole. This is surprising, as the province is the third largest of the country and has the highest population density. At the same time, this evidence is supportive of our idea that low levels of civicness

\footnotetext{
${ }^{9}$ Firms with negative values for variables such as service purchases, sales, employees, fixed assets, age are excluded. Moreover, observations whose value of PSI is larger than the 99.5th percentile of the PSI distribution are dropped from the regressions.
} 
may hinder service outsourcing, since the province of Naples has the lowest endowment of civic capital in Italy according to our measures.

Figure 2 shows that the geographic pattern of PSI shown in Figure 1 is not driven by the spatial sorting of industries with higher average PSI in the Center-North: even after removing the variation in PSI that is explained by industry affiliation, service outsourcing

is still higher in the North of the country 10 Besides a pronounced North-South gap, the graph suggests that PSI is highest in the areas with the greatest endowment of civic capital (Center-North of the country).

\subsection{Measurement of civic capital}

We quantify the stock of civic capital in a given province by three proxies, namely electoral turnout in referenda, blood donations in 2000, and volunteering in non-profit organizations in 2002, with the latter two variables being standardized by population 11 These variables are standard measures for civic capital in the literature (Guiso et al., 2004; Buonanno et al., 2009; de Blasio and Nuzzo, 2010). The motivation to use them as proxies descends from the following reasoning. Individuals that donate blood, vote in referenda, or volunteer in non-profit organizations make an effort without receiving any personal or pecuniary compensation. Individuals who pursue these activities deviate from narrow-minded self-interested behavior and express a concern for the common good. Therefore, these activities can be considered as an expression of those societal values and beliefs prevailing in the local area that sustain cooperation. This is precisely the behavioral trait civic capital aims to capture. The incidence of these activities at the local level informs about the strength of cooperative values and beliefs in a given province. Obviously, each of these proxies is only an imperfect measure of civic capital. In order to purge these proxies of noise, we extract the first principal component. As expected, we find a strong common pattern in the data. All three proxies are highly correlated and the eigenvalue of the first principal component is 2.48 while

\footnotetext{
${ }^{10}$ Specifically, Figure 2 shows average provincial residuals obtained from regressing the log of PSI on the full set of 3-digit industry dummies.

${ }^{11} \mathrm{~A}$ complete description of the variables is provided in the appendix.
} 
the associated eigenvector explains $75 \%$ of the total variance.

Figure 3 shows the geographic variation of civic capital across Italian provinces when measured by the first principal component. The map confirms the well-established NorthSouth divide in the endowment of civic capital. Provinces in the Centre-North have a high stock of civic capital whereas the endowment of civic capital in the South is considerably lower. Comparing the geographic distribution of civic capital with average provincial PSI, net of industry effects, in Figure 2 reveals striking similarities. The sharp North-South gap in the endowment of civic capital coincides almost perfectly with the spatial pattern of PSI. Moreover, the Central-Northern regions with the highest PSI are those where the stock of civic capital is the largest. The analogy between the two maps provides strong visual evidence of a positive relationship between civic capital and the extent of service outsourcing.

In section 6 we use historical variables of civic capital as instruments. The first measure is average electoral turnout in elections during the period 1919-1921. The second historical measure is membership in mutual aid societies in 1873, standardized by population. These mostly urban associations served craftsmen and artisans as a form of insurance against economic and social calamities. Both variables are available at the regional level 12 The last historical instrument delves even deeper into history. According to Putnam (1993), the differences in civic capital across Italy were determined by different political regimes prevailing at the beginning of the second millennium. In particular, he stresses the role of free-city states that emerged in the Northern part of the country for the accumulation of civic capital. Based on information provided in Guiso et al. (2008), we count for each province the number of cities that were recorded free-city states in the year 1300 .

\subsection{Control variables}

In the regressions, we use control variables that capture relevant characteristics of the firm as well as local attributes of the province where the firm is located. First, the firm capital stock (total tangible fixed assets) and the number of employees are included. The two factors of

\footnotetext{
${ }^{12}$ For a detailed description consult $\overline{\text { Putnam }}$ (1993).
} 
production are important controls, as they tend to influence firm-level demand in services. For example, the larger the stock of machinery, the greater the expenditure for services like repair and maintenance. At the same time, the stocks of capital and labor are proxy for the the existence of economies of scale in internal service provision (Abraham and Taylor, 1996). Larger firms realize economies of scale in in-house production of services which make service outsourcing less attractive. The age of the firm is also included.

At the local level, we employ the size of the service market, calculated as the total number of service workers employed in each province in the years from 2001 to 2007. When a firm in the sample belongs to the service sector, we subtract its size from the overall number of service workers in the local area. The decision of the firm to outsource a given input depends on the search costs for finding the appropriate supplier (Grossman and Helpman, 2002). This is particularly important in the case of services which are typically less standardized and require a high level of customization. Greater local availability of service providers reduces search costs and improves the match between the client and the supplier. Moreover, the size of the local service market controls for the effect of agglomeration on contractual hazards. For example, in a buyer-supplier relationship, the threat of holding-up the contract partner is less severe in agglomerated areas, due to the high number of potential alternative buyers (Helsley and Strange, 2007). Hence, we expect a positive relationship between the size of the local service market and the extent of service outsourcing of firms.

Next, we account for the quality of formal contracting institutions, which is an important determinant of contracting costs. We measure the performance of contracting institutions at the local level by the average number of days it takes for a civil proceeding to be completed in the tribunals located in the province 13 Consequently, service outsourcing should be higher in those provinces where proceedings are shorter. We also include the number of bank branches, normalized by population. As in Benfratello et al. (2008), we posit that the number of bank branches is related to the local degree of financial development. Financial development, in turn, may be correlated to PSI trough a number of channels. It could promote the birth of

\footnotetext{
${ }^{13}$ In some province there is more than one tribunal. We calculate the average for each province over all courts located in the province.
} 
innovative suppliers providing specialized services, thus increasing outsourcing. By inducing firm entry and hence the degree of competition, financial development may drive smaller, non-integrated firms out of the market, thereby increasing the equilibrium level of vertical integration. Alternatively, given that larger firms are more vertically integrated, the fact that financial development increases competition could also reduce the average degree of vertical integration in an industry: more intense competition and hence lower profits reduce

the growth of firms and their size (Macchiavello, 2012). As service industries tend to be skill-intensive, another variable which can be linked to the availability of a large set of service varieties is the number of skilled workers. This variable is measured by the share of the provincial population holding a university degree.

\section{Econometric specification}

In the basic setup, we assess the impact of civic capital on PSI by focusing on the following static model specification:

$$
\ln P S I_{i, j, s, t}=\alpha_{0}+\alpha_{1} C C_{j}+\mathbf{X}_{i, t}^{\prime} \boldsymbol{\beta}+\alpha_{2} \ln S_{j, t}+\mathbf{Z}_{j}^{\prime} \boldsymbol{\delta}+\gamma_{r}+\gamma_{s}+\gamma_{t}+\epsilon_{i, j, s, t}
$$

where $P S I_{i, j, s, t}$ is the purchased service intensity of firm $i$ in province $j$, 3-digit industry $s$, at time $t ; C C_{j}$ is the variable of main interest, i.e. the stock of civic capital in province $j . \mathbf{X}_{i, t}$ is a vector of time-varying firm level controls, which include number of employees, capital stock, and firm age. As for the controls at the province level, $S_{j, t}$ is the time-varying size of the local service market, while the vector $\mathbf{Z}_{j}$ collects time-invariant provincial covariates, namely the length of trials, the stock of human capital, and financial development. Both the dependent variable and the regressors are log-transformed, with the exception of the principal component. We control for specific features at the regional level through a set of 20 regional dummy variables, $\gamma_{r}$, to minimize the impact of unobserved geographic heterogeneity on PSI. Moreover, the equation includes a full set of 3-digit industry dummies, $\gamma_{s}$, that account for systematic differences in service outsourcing across industries, and a full set of time dummies, $\gamma_{t}$, that capture common time effects. At this stage, all the explanatory variables, including the stock of civic capital, are assumed to be strictly exogenous. The 
static model is estimated by pooled OLS over the years 2001 through 2007. Unobserved heterogeneity is expected to be adequately controlled for by the set of regional, sector and time dummies. The standard errors are made robust to heteroskedasticity and clustered at the province level, as required by the inclusion of aggregate regressors (Moulton, 1990).

Since service purchases from external providers are likely affected by past decisions of the firm, thus possibly inducing high persistence, we also analyse the dynamic nature of outsourcing by means of a suitable econometric strategy. Hence, we turn to a dynamic model specification which allows to disentangle state dependence of PSI, through the lagged dependent variable, from firm-level heterogeneity, through the inclusion of individual time invariant effects. The dynamic model we consider is the following:

$\ln P S I_{i, j, s, t}=\alpha_{0}+\alpha_{1} \ln P S I_{i, j, s, t-1}+\alpha_{2} C C_{j}+\mathbf{X}_{i, t}^{\prime} \boldsymbol{\beta}+\alpha_{3} \ln S_{j, t}+\mathbf{Z}_{j}^{\prime} \boldsymbol{\delta}+\mu_{i}+\gamma_{t}+\epsilon_{i, j, s, t}$

where the $\mu_{i}$ are the time-invariant individual effects capturing firm-level unobserved heterogeneity constant over time, and the lagged dependent variable $P S I_{i, j, s, t-1}$ enters among the regressors. Common time effects are captured by $\gamma_{t}$, a full set of year dummies. All non-binary variables are log-transformed, with the exception of the principal component.

In such a dynamic specification the lagged dependent variable is endogenous due to unobserved individual heterogeneity. Furthermore, the one-way fixed effect estimator would suffer from the Nickell (1981) bias due to the correlation between the lagged regressor and the error term, induced by the within-group transformation; the fixed effect estimator would also prevent us from identifying the effect of civic capital, which is time-invariant. To address the endogeneity issue and still be able to identify the effects of time-invariant regressors, we estimate equation (44) by the System GMM estimator for dynamic panel data models proposed by Blundell and Bond (1998). This approach builds, for each time period, a system stacking two equations for the model in (44), one in first differences, i.e. the transformed model, and one in levels, i.e. the original model. The system is estimated by GMM exploiting moment conditions where lagged levels of the dependent variable are used as instruments for the equations in first differences and lagged first-differences are used as instruments for the equations in levels. The System GMM (SYS-GMM) approach has the advantage of explicitly taking into account the unobserved firm-level heterogeneity and allowing for the 
identification of the effect of time-invariant regressors, while only requiring mean stationarity of the initial conditions. We test the validity of the moment conditions exploited by the SYSGMM estimator using the Hansen (1982) test of overidentifying restrictions. The standard errors are made robust to heteroskedasticity and clustered at the province level.

\section{Results}

\subsection{Estimates of the static and dynamic specifications}

In Table 2 we first present the pooled OLS estimates of equation (3). In each of the first three columns, we exploit one of the three alternative proxies of civic capital at a time, while column (4) shows the result for the model in which civic capital is measured by the first principal component of the three proxies. In general, the estimated coefficients suggest a positive relationship between the stock of provincial civic capital and firm-level PSI. The relationship between civic capital and service outsourcing is statistically significant in the case of referendum turnout and the first principal component of the three proxies. However, when civic capital is measured through blood donations and volunteers the coefficient is not statistically different from zero.

In columns (5) and (6) we report the pooled OLS estimates of a dynamic specification of equation (3), where we add the one-year lag of the dependent variable to the set of regressors. The estimated coefficient of the lagged dependent variable points to a strong persistence of firm-level PSI. There are several explanations for this result, ranging from organizational sluggishness to the inertia created by the fact that contracts regulating service purchases tend to span over many years. Results are consistent with the idea that civic capital favors service outsourcing. However, the endogeneity of the lagged dependent variable in a dynamic framework where the estimation method is OLS poses a threat to the reliability of the results.

In columns (7) and (8) we present the SYS-GMM estimates of the dynamic specification in equation (4). The lagged dependent variable is treated as endogenous, whereas the total number of workers and level of capital are treated as predetermined, not strictly exogenous: the set of instruments in levels for the first-difference equation includes lags $t-3$ and $t-4$ of 
the dependent variable and lags $t-1$ through $t-4$ of workers and capital; for the equation in levels, we exploit for the first-difference instruments the same lag structure (lags $t-3$ and $t-4$ of the dependent variable, and lags $t-1$ through $t-4$ for workers and capital). The instrument matrix is collapsed (Roodman, 2009) to limit the scope for instrument proliferation.

The GMM estimates suggest a positive relationship between civic capital (proxied by the referendum turnout and the principal component) and service outsourcing. The GMM coefficients of civic capital are close in magnitude to the ones provided by the baseline pooled OLS estimates of columns (1) and (4). In the case of the referendum turnout, an estimated elasticity equal to 0.28 means that a $10 \%$ difference in the provincial turnout is associated with a $2.8 \%$ firm-level difference in PSI. To give an idea of the economic magnitude of the effect of civic capital when the measure is the first principal component we do the following back-of-the-envelope calculations. An estimated coefficient equal to 0.02 implies that PSI would be $10 \%$ larger if Naples had the same stock of civic capital of Milan. The actual difference in the degree of service outsourcing in the data between firms located in Milan and Naples is $9.9 \%$ (i.e. $22.6 \%$ vs. $12.7 \%$ ) 14

\section{[Insert Table 2 about here]}

Turning to the province-level controls, the size of the service market, measured by the numbers of workers employed, has a statistically significant effects. It suggests that firms in thick markets purchase relatively more services from external suppliers, in line with the findings of Ono (2007). Regarding the firm-level controls, the number of employees is negatively associated with PSI, pointing to the existence of economies of scale in the production of services at the firm level. Since in-house production of services is subject to fixed costs, smaller firms with lower service consumption outsource more. This result has been found in other studies (Abraham and Taylor, 1996; Merino and Rodrand, 2007). The amount of fixed assets, given the other controls, is positively related to PSI. In this case, the

\footnotetext{
${ }^{14}$ The principal component for Naples is -3.347 , while for Milan it is +1.236 . The contribution from the difference in civic capital to the difference of PSI in $\log$ terms for the two locations is then equal to 0.10 , which corresponds to a difference of roughly $10 \%$ in levels.
} 
rise in external service expenditure relative to sales could be due to an increased demand for capital-related services, such as maintenance or repairing. The sign of the coefficient of the age of the firm is unstable, and changes when we add the lag of the dependent variable among the regressors.

SYS-GMM estimates confirm a very high persistence of the intensity of service outsourcing over time, the coefficient on the lagged dependent being around 0.8. The $p$-value of the Hansen $J$-test for overidentifying restrictions $(p=0.11)$ shows the validity of the full instrument set which is exploited by the SYS-GMM estimator.

\subsection{Robustness checks}

In Table 3 we present several robustness checks. In columns from (1) to (5) we display the pooled OLS estimation of equation (3), while in columns from (6) to (10) we present the GMM estimation of equation (4). From now on we will describe the results obtained with the principal component of civic capital in the main text. Estimates with referendum turnout can be found in the appendix B with supplementary material.

[Insert Table 3 about here]

In columns (1) and (6) we allow nonlinearities in firm-level variables by including squared controls. In the GMM specification, also squared controls are instrumented with appropriate time lags. In columns (2) and (7) provincial GDP is included as an additional regressor, while in columns (3) and (8) the provinces of Milan, Rome and Turin are excluded. Finally columns (4) and (9) show results obtained restricting the sample to the firms belonging to the manufacturing sector (NACE 15 to 36), and columns (5) and (10) to those operating in services (NACE greater than 40, except industries mentioned in footnote 5). In all these cases the coefficient of civic capital is statistically significant and stable compared to the baseline estimates. Only for the pooled OLS estimates of PSI in manufacturing firms, column (4), we get a civic capital coefficient that is not statistically different from zero. However, the coefficient is statistically significant with the SYS-GMM estimator of column (9), and in both the pooled OLS and SYS-GMM regressions obtained employing referendum turnout 
instead of the principal component, which are reported in the appendix $\mathbb{B}$. The $p$-value of the Hansen $J$-test for overidentifying restrictions is fairly low in some columns, and then the validity of the full instrument set is not granted. However, also in these cases the point estimate of the civic capital variable stays remarkably constant around a value of 0.02 .

In section 3 we showed that PSI contributes in an inverse manner to the overall firm-level degree of vertical integration, measured by value added over sales. We have also explained why, given our interest in civic capital, PSI is the most appropriate measure to look at. Nonetheless, it may be interesting to show what happens if we replace PSI with value added over sales, given that this measure is widely used in the literature on outsourcing. We do so in the appendix and find that, as expected, results are inconclusive. By adding transactions involving material inputs to retrieve the overall degree of vertical integration, the incidence of contractual hazards becomes less acute, especially in the case of homogenous raw materials. Moreover, the exact location of the input supplier is uncertain, and consequently the right level of civic capital that should be assigned to economic transactions is unclear. Therefore, it comes as no surprise that the effect of civic capital is not statistically different from zero.

\section{Assessing causal channels through historical instru- ments}

\subsection{Motivation and identifying assumptions}

The econometric specification in equation (3) assumes that, conditional on the covariates, the stock of civic capital is uncorrelated with the error term $\epsilon_{i, j, s, t}$. If this assumption is not satisfied, we may get a spurious relationship between civic capital and PSI. Imagine a thriving province with many service providers, and an efficient judiciary system, financial sector, etc. In such a business environment, firms may have a high tendency to purchase services from external suppliers. If economic prosperity fosters civic behaviour as well, we may observe positive association between civic capital and PSI that does not follow from a causal relationship. Similarly, inconsistent estimates may arise also if civic capital is 
measured with error even after extracting the principal component of our three proxies.

In the following, we address endogeneity concerns related to omitted variables or measurement error by instrumenting civic capital with historical measures. We follow de Blasio and Nuzzo (2010) and Bürker and Minerva (2014) for the choice of historical instruments. Instrumenting civic capital with historical measures is a widely adopted strategy in the literature aimed at establishing a causal relationship between civic capital and socio-economic outcomes (de Blasio and Nuzzo, 2010; Tabellini, 2010; Guiso et al., 2016). Deeply lagged measures of civicness are natural candidates for instruments as civic behavior tends to be highly persistent over time.

The first set of instruments that we use measures civicness through electoral turnout in the 1920s and membership in mutual aid societies that emerged in the late 19th century. Individuals that participate in political elections express a concern for common good. Putnam (1993) argues that electoral turnout at the beginning of the 20th century is likely to be driven by civic-minded behavior as voter turnout strongly correlates with other measures of social solidarity. The measure of electoral turnout in the 1920s, the first with male universal suffrage, is an average of voter participation over two national elections from 1919 and 1921 and two communal elections from 1920.

As to mutual aid societies, they were created in the middle of the 19th century as a response to the economic and social hardships brought about by industrialization. These aid societies provided to their members basic services such as medical care and insurance against work accidents. Putnam (1993) stresses that the disposition to cooperation necessary for the functioning of mutual aid societies was sustained by mutual reciprocity rather than formalized enforcement and monitoring. As such, they express values and beliefs similar to the traits civic capital aims to capture. The importance of mutual aid societies at the local level is measured by the membership rate, i.e. the number of members in mutual aid societies per 100,000 inhabitants. This information is available at the regional level and refers to the year 1873 .

The second set of historical variables goes back to the Middle Age and captures information on the free city states that existed before 1300 in Northern Italy. Lacking any 
central power, free-city states were created by their citizens to address problems of common interest, in particular to provide mutual security. These city states were characterized by a high degree of civic participation in the political decision processes, at least for Middle Age standards. The free-city state experience favored the creation of horizontal ties and a strong sense of civic cooperation. Guiso et al. (2016) show how these cooperative values and beliefs persist until today. Based on information provided in Guiso et al. (2008), we count for each province the number of free-city states that existed before 1300 . The resulting variable varies between 0 and 3 . As the free-city states existed predominantly in the North and Center of the Italian peninsula, the South and Islands are not included in the regressions 15

In order to be valid, the instruments must affect PSI only through the contemporaneous stock of civic capital. The empirical literature on civic capital has acknowledged that this might not be straightforward (Durlauf, 2002; Tabellini, 2010; Guiso et al., 2011). The main challenge is that the historical episodes that determined the accumulation of civic capital might have also boosted other assets (e.g. the artistic heritage of cities) omitted from the regression that persist until today and influence the outcome of interest. If this were the case, the exclusion restriction would be violated and the instruments would no longer be valid. We address this concern in the following manner. First, while most of the literature aims at assessing the link between civicness and economic development, here we study outsourcing of business services. Dealing with a specific firm-level outcome mitigates the risk of violation of the exclusion restriction. As we focus on a narrow dimension of firm activity such as outsourcing decisions, the explanatory variables included in the regression should capture all relevant factors affecting the outcome. Second, we include the provincial degree of urbanization in 1861 as an additional control. Mutual aid societies predominantly insured against economic and social calamities craftsmen and artisans living in cities. As such, they were mostly an urban phenomenon. Hence, including historical urbanization in 1861 among the regressors improves the reliability of the instrument with respect to the

\footnotetext{
${ }^{15}$ Specifically, the regions of Campania, Molise, Puglia, Basilicata, Calabria, Sicily, and Sardinia are dropped.
} 
exclusion restriction, because it wipes out confounding factors related to urbanization at the time the instrument were measured. By the same token, historic urbanization may capture unobserved provincial characteristics, correlated with the presence of free-city states in the Middle Age, that affect the current stock of civic capital.

\subsection{Results with historical instruments}

In column (1) of Table 4 we present the estimates of equation (3) where the regional fixed effects have been replaced with dummies for the five macro-regions of the country: NorthWest, North-East, Center, South, and Islands. This choice is motivated by the fact that the data on mutual aid societies and turnout in the 1920s are available only at the regional level. In addition to that, in column (2), Southern regions are excluded from the estimating sample for comparability with the regressions involving free-city states. Compared to the baseline regression, the coefficient of civic capital in column (1) is larger in magnitude, possibly due to the inclusion of macro-region dummies. When excluding the South and the islands, the sample variation in civic capital and overall socio-economic performance is substantially reduced. Column (2) shows that the results are robust to such an exclusion, supporting the overall reliability of our findings. Column (3) presents the dynamic counterpart of column (2), estimated by SYS-GMM: the high persistence of service outsourcing is confirmed, as well as the role of civic capital.

[Insert Table 4 about here]

To address potential endogeneity of civic capital, we adopt an IV approach which exploits the historical instruments presented above. The first set of instrumental variables for civic capital includes the electoral turnout in the 1920s and the number of mutual aid societies.

We first rely on two-stage least squares (2SLS), and we include in both stages the full set of covariates augmented with urbanization in 1861. In columns (4) through (6) we employ the two IVs, both separately and jointly. The first stage estimates, reported in Panel B, present a positive sign for the IV coefficients and point to the relevance of the accumulated stock of civic capital over time in determining current civicness. With respect to the rele- 
vance of the IVs, the F-statistics for the excluded instruments is large and both variables are jointly significant 16 The second stage results are reported in Panel A. A positive and significant estimated coefficient for civic capital suggests that civicness favors business service outsourcing of firms in line with the OLS estimates, but the magnitude of the 2SLS coefficient is larger. IV coefficients larger than the corresponding OLS estimates are frequently found in the related literature (Acemoglu et al., 2001; Tabellini, 2010; Guiso et al., 2016; Gorodnichenko and Roland, 2017). Acemoglu et al. (2001) and Gorodnichenko and Roland (2017) argue that the increase is likely to be driven by measurement error. This would imply that even after extracting the principal component, civic capital is still noisily measured, thus introducing a downward bias in OLS. Hence, the 2SLS estimation helps to identify the true impact of civic capital on service outsourcing of firms. A possible alternative explanation for larger estimated coefficients is that the instruments affect service outsourcing through channels other than civic capital, even after conditioning on historical urbanization and the other regressors. To further investigate this issue, we estimate the outcome model by SYS-GMM, using the historical IVs (turnout in 1920s and number of mutual aid societies). Column (7) reports the GMM estimates of equation (41) for the full sample adding historical urbanization to the regressors. The results are consistent with the corresponding 2SLS estimates, the most remarkable findings being the high persistence of outsourcing and the relevance of civicness, even once the dynamics is accounted for. We test the validity of the full set of overidentifying restrictions by means of the Hansen test: a $p$-value of 0.15 points to the validity of the IVs. Most notably, the Difference-in-Hansen test on the historical IVs ( $p$-value 0.596$)$ supports the choice of our exclusion restrictions 17

Finally, in the last two columns we instrument civic capital with the number of free-city states that existed before 1300 in each province. The 2SLS results from the first stage, reported in column (8), show that the instrumental variables are relevant. The presence of a free-city state in a province significantly increases the stock of civic capital compared to provinces with no free-cities. The increase in the current stock of civic capital is even larger

\footnotetext{
${ }^{16}$ As for identification, the Kleibergen-Paap and Anderson-Rubin test statistics point to a genuine model identification. These tests are not reported in the table to save on space.

${ }^{17}$ This test is not reported in the table to save on space.
} 
if the province hosted two free-city states 18 The three instrumental variables are jointly significant with a satisfactory F-statistic. The second stage results in panel A confirm previous findings. Even when instrumented with historical events dating back to the late Middle Age, civic capital positively affects contemporary service outsourcing of firms. The magnitude of the estimated 2SLS coefficient is slightly smaller than its OLS counterpart of column (2). Column (9) presents System GMM estimates similar to those in column (3), with the addition of free-city dummies among the excluded instruments. The exclusion restrictions are valid, as confirmed by the Hansen test for overidentifying restrictions and by an unreported Difference-in-Hansen test on historical IVs.

Overall, the historical IV regressions produce a coherent picture, independently of whether we instrument civic capital with measures of civic participation that refer to the first decades after the Italian unification or with historical events that occurred during the Middle Age.

\section{Conclusions}

This paper provides empirical evidence that civic capital shapes the firms' intensity of service outsourcing. The results can be attributed to the fact that, in more civic areas, the incidence of opportunistic behavior on the part of the contracting parties is reduced, and this is something which improves contractual outcomes and sustains more market exchange between independent firms.

Understanding the firm's choice of whether to produce a given input or purchase it from external suppliers is a fundamental concern in economics. Despite several influential theories and a huge amount of empirical studies, the pronounced differences that exist in the organization of production of firms are not yet fully understood. Analyzing the importance of informal institutions, and in particular the role of cooperative values that prevail in a given area, might advance our understanding of the determinants of the costs of contracting,

\footnotetext{
${ }^{18}$ We are not particularly worried by the fact that having three free cities in 1300 is not statistically related to a higher level of civic capital today. Notice that there are just three provinces with 3 free-city states (Alessandria, Cuneo and Turin) and they are all located in Piedmont. We believe that there is not enough variability to warrant the identification of the free-city effect in this case.
} 
a crucial aspect at the heart of most of the theoretical contributions in this field.

At the same time our analysis sheds some light on why civic capital spurs aggregate economic performance. While in general it is not straightforward to establish a direct relationship between firms' organization and performance, there is some evidence that firms might benefit from greater service outsourcing. Intuitively, outsourcing allows to concentrate on core activities and to benefit from greater specialization. Similarly, firms that produce a wider range of inputs might face larger governance costs associated with running a less specialized organization. These effects might be particularly pronounced for services, which are often ancillary inputs with respect to the main product line. Our paper uncovers a channel that helps to explain the positive effect of civic capital on service outsourcing and, consequently, aggregate economic performance.

\section{References}

Abraham, K. and S. Taylor, 1996: Firms' use of outside contractors: Theory and evidence. Journal of Labor Economics, 14(3), 394-424.

Abramovsky, L. and R. Griffith, 2006: Outsourcing and Offshoring of Business Services: How Important is ICT? Journal of the European Economic Association, 4(2-3), 594-601.

Acemoglu, D., S. Johnson, and T. Mitton, 2009: Determinants of Vertical Integration: Financial Development and Contracting Costs. Journal of Finance, 64(3), 1251-1290.

Acemoglu, D., S. Johnson, and J. Robinson, 2001: The colonial origins of comparative development: An empirical investigation. American Economic Review, 91(5), 1369-1401.

Adelman, M., 1955: Concept and Statistical Measurement of Vertical Integration. In Business Concentration and Price Policy. Princeton University Press, Princeton NJ.

Algan, Y. and P. Cahuc, 2014: Trust, Growth, and Well-Being: New Evidence and Policy Implications. In Handbook of Economic Growth, volume 2 of Handbook of Economic Growth. Elsevier, 49-120.

Baker, G., R. Gibbons, and K. J. Murphy, 2002: Relational Contracts And The Theory Of The Firm. The Quarterly Journal of Economics, 117(1), 39-84.

Benfratello, L., F. Schiantarelli, and A. Sembenelli, 2008: Banks and innovation: Microeconometric evidence on Italian firms. Journal of Financial Economics, 90(2), 197-217.

Bloom, N., R. Sadun, and J. V. Reenen, 2012: The organization of firms across countries. Quarterly Journal of Economics, 127(4), 1663-1705.

Blundell, R. and S. Bond, 1998: Initial conditions and moment restrictions in dynamic panel data models. Journal of Econometrics, 87(1), 115-143. 
Bürker, M. and G. A. Minerva, 2014: Civic capital and the size distribution of plants: short-run dynamics and long-run equilibrium. Journal of Economic Geography, 14(4), $797-847$.

Buonanno, P., D. Montolio, and P. Vanin, 2009: Does Social Capital Reduce Crime? Journal of Law \& Economics, 52(1), 145-170.

Cartocci, R., 2007: Mappe del tesoro: Atlante del capitale sociale in Italia. Il Mulino, Bologna.

Coase, R., 1937: The Nature of the Firm. Economica, 4, pp. 386-405.

de Blasio, G. and G. Nuzzo, 2010: Historical traditions of civicness and local economic development. Journal of Regional Science, 50(4), 833-857.

DeBandt, J., 1996: Business services: Markets and transactions. Review of Industrial Organization, 11(1), 19-33.

Durlauf, S. N., 2002: On the empirics of social capital. Economic Journal, 112(483), F459-F479.

Galdon-Sanchez, J. E., R. Gil, and A. Bayo-Moriones, 2015: Outsourcing of peripheral services: Evidence from Spanish manufacturing plant-level data. European Economic Review, 78(C), 328-344.

Gorodnichenko, Y. and G. Roland, 2017: Culture, Institutions, and the Wealth of Nations. Review of Economics and Statistics, 99(3), 402-416.

Görg, H. and A. Hanley, 2011: Services Outsourcing And Innovation: An Empirical Investigation. Economic Inquiry, 49(2), 321-333.

Grossman, G. M. and E. Helpman, 2002: Integration versus Outsourcing in Industry Equilibrium. Quarterly Journal of Economics, 117(1), 85-120.

Guiso, L., P. Sapienza, and L. Zingales, 2004: The Role of Social Capital in Financial Development. The American Economic Review, 94(3), 526-556.

Guiso, L., P. Sapienza, and L. Zingales, 2008: Long Term Persistence. NBER Working Papers 14278, National Bureau of Economic Research.

Guiso, L., P. Sapienza, and L. Zingales, 2011: Civic Capital as the Missing Link. volume 1 of Handbook of Social Economics. North-Holland, 417 - 480.

Guiso, L., P. Sapienza, and L. Zingales, 2016: Long-Term Persistence. Journal of the European Economic Association, 14(6), 1401-1436.

Helsley, R. W. and W. C. Strange, 2007: Agglomeration, opportunism, and the organization of production. Journal of Urban Economics, 62(1), 55-75.

Lafontaine, F. and M. Slade, 2007: Vertical Integration and Firm Boundaries: The Evidence. Journal of Economic Literature, 45(3), 629-685.

Li, B. and Y. Lu, 2009: Geographic concentration and vertical disintegration: Evidence from China. Journal of Urban Economics, 65(3), 294-304. 
Macchiavello, R., 2012: Financial Development and Vertical Integration: Theory and Evidence. Journal of the European Economic Association, 10, 255-289.

Merino, F. and D. Rodrand, 2007: Business services outsourcing by manufacturing firms. Industrial and Corporate Change, 16(6), 1147-1173.

Moulton, B. R., 1990: An Illustration of a Pitfall in Estimating the Effects of Aggregate Variables on Micro Units. The Review of Economics and Statistics, 72(2), 334-338.

Nickell, S., 1981: Biases in Dynamic Models with Fixed Effects. Econometrica, 49(6), $1417-1426$.

Ono, Y., 2003: Outsourcing business services and the role of central administrative offices. Journal of Urban Economics, 53(3), 377-395.

Ono, Y., 2007: Market thickness and outsourcing services. Regional Science and Urban Economics, 37(2), $220-238$.

Putnam, R., 1993: Making Democracy Work: Civic Traditions in Modern Italy. Princeton University Press.

Roodman, D., 2009: A Note on the Theme of Too Many Instruments. Oxford Bulletin of Economics and Statistics, 71(1), 135-158.

Schwartz, A., 1993: Subservient Suburbia - The Reliance of Large Suburban Companies on Central City Firms for Financial and Professional Services. Journal of the American Planning Association, 59(3), 288-305.

Tabellini, G., 2010: Culture and institutions: Economic development in the regions of Europe. Journal of the European Economic Association, 8(4), 677-716.

Williamson, O. E., 1975: Markets and Hierarchies: Analysis and Antitrust Implications.

Williamson, O. E., 1979: Transaction-Cost Economics: The Governance of Contractual Relations. Journal of Law and Economics, 22(2), 233-261.

Williamson, O. E., 1985: The Economic Institutions of Capitalism.

Williamson, O. E., 1993: Calculativeness, trust, and economic organization. The Journal of Law \&s Economics, 36(1), 453-486.

Williamson, O. E., 1996: The Mechanisms of Governance. Oxford University Press, New York.

\section{A Appendix}

\section{A.1 Detailed description of the data}

\section{A.1.1 Definition of Purchased Services}

Under the Italian accounting system, the exact amount of purchased services is reported in a specific item in the profit and loss account of each firm in the section dedicated to the costs of production. This item contains all the services expenses coming from ordinary firm 
activity. The list that follows provides some of the most common services purchases: Travel and accommodation expenses - Repairing and maintenance carried out by external firms - Intermediate production stages outsourced to external firms - Advising in the technical, legal, fiscal, administrative, commercial and accounting fields - Advertising and marketing - Commissions and reimbursement of expenses for agents and representatives - Vigilance and security - Cleaning - Remunerations and reimbursements paid to administrators and auditors - Costs for the personnel temporary hired from other firms - Costs for the canteen, nursery school, holiday camps, employees clubs, etc. (these costs are net of the amount of money that is to charged to employees) - Costs for luncheon vouches distributed to employees - Costs for refresher courses for employees - Costs for board and lodging of employees in secondment - Electricity, telephone, fax, water, gas, and other utilities. The item B7 also lists costs for services provided by banks and financial agencies different from true financial charges. Those include: rental fees for safe-deposit boxes, service payments for utilization fees, costs for safe-keeping of bonds, commissions for bond bails (if not held to obtain financing), expenses and commissions for factoring (excluding financial charges), expenses for valuation of real estates to obtain loans, expenses for preliminary investigations of real estates and financing (in general, all those expenses different from interests and discounts, commissions of financing and bank charges and their collateral.)

\section{A.1.2 Measures or instruments for civic capital}

Referenda turnout: It is the average provincial electoral turnout for the referenda on the choice between republic and monarchy (1946), divorce (1974), public financing of political parties (1978), public security and anti-terrorism measures (1981), abortion (1981), wage escalator regulations (1985) and nuclear power and hunting regulations (1987). The following eight provinces were created after 1995: Biella, Lecco, Lodi, Rimini, Prato, Crotone, Vibo Valentia, Verbano-Cusio-Ossola. The provinces to which they belonged before 1995 and whose value has been assigned to them appear in parenthesis: Biella (Vercelli), Lecco (simple average of Bergamo and Como), Lodi (Milan), Rimini (Forlì-Cesena), Prato (Firenze), Crotone (Catanzaro), Vibo Valentia (Catanzaro), Verbano-Cusio-Ossola (Novara). The source of data for referendum turnout is the Ministry of the Interior.

Blood donations: The number of blood donations per 1000 inhabitants, disaggregated by province. The data are collected from the health authorities of Italian regions. In each region, regional health authorities collect data on blood donations and subsequently send this information to the High Institute for Health (Istituto Superiore di Sanità) which, in turn, maintains a National and Regional Registry of Blood and Plasma. Provincial data on blood donations are not available for Apulia and Lazio. For the provinces of these two regions we take the total regional value. Data refer to the year 2002 and the source is Cartocci (2007).

Volunteers: It is the number of volunteers in non-profit organizations. Data refer to the year 2000 and the source is de Blasio and Nuzzo (2010).

Turnout in 1920s: It is the average electoral turnout at the regional level in the national elections of 1919 and 1921, provincial elections in 1920 and communal elections in 1920. There is no data for the regions of Valle d'Aosta, Trentino-Alto Adige and Friuli-Venezia Giulia. We adopt the values of Piedmont for Valle d'Aosta, the region from which it was split off. For the latter two regions, we adopt the values of Veneto, which is socio-geographically the closest one. The source of these data is Putnam (1993).

Mutual aid societies in 1873: It is the number of the members in mutual aid societies in 1873 at the regional level, standardized by 100,000 inhabitants. Data for Valle d'Aosta, 
Trentino-Alto Adige and Friuli-Venezia Giulia are missing. We adopt the values of Piedmont for Valle d'Aosta, the region from where it was split off. For the latter two regions, we adopt the values of Veneto, which is socio-geographically the closest one. Additionally, there is no data for Molise, for which we take the value of Abruzzo, the region from where it was split off. The source is Putnam (1993).

Number of free-city states in 1300: It is the number of free-city state experiences in the territory of each province in 1300. Data are from Guiso et al. (2008). In order to reduce the cost of collecting historical data at the town level, the authors analyze the history of the 400 biggest cities in terms of 1871 population in the area that was under the Holy Roman Empire at the beginning of the second Millennium (basically, the Center-North of Italy).

\section{A.1.3 Other provincial explanatory variables}

Service workers: It is the number of total service workers in the province. We take this information from the universe of Italian enterprises coming from Archivio Statistico delle Imprese Attive (Statistical Archive of Active Enterprises) administered by Istat. The data refer to the years from 2001 to 2007 and are extracted for the interval of two-digit industries $50-74$.

Total workers: It is the number of total workers in the province (full-time equivalent of workers hired in every sector). We take this information from Istat. The data refer to the years from 2001 to 2007 (http://www3.istat.it/salastampa/comunicati/non_calendario/20100114_00/).

University graduates: It is the number of university graduates per 100 inhabitants, disaggregated by province. Data are from Istat.

Bank branches: It is the number of bank branches per 10,000 inhabitants, disaggregated by province. Data are from the Bank of Italy's Base Informativa Pubblica.

Length of labor trials: It is the number of days it takes to complete a first degree trial in labor affairs in each of the 165 Italian labor courts. The data refer to the years from 1995 to 2001 (earlier years are not available) and are provided by Istat in the data base Territorial Information System on Justice (Sistema Informativo Territoriale sulla Giustizia). Since there are more courts than provinces and since in some cases the territory of a court belongs to two different provinces we proceed as follows. First, we assign to each city in the province the value of the court to which the city belongs. This information is then averaged over all the cities belonging to the same province to get a provincial variable.

$G D P$ : It is the provincial nominal gross domestic product, expressed in thousands of euros. The source is Istat.

Urbanization in 1861: This variable is the share of total provincial population living in cities with more than 10,000 inhabitants in 1861. Data on city size come from the "Italian Urban Population Database 1300-1861", provided by Paolo Malanima

(http://www.paolomalanima.it/default_file/Page646.htm). The number of total provincial population in 1861 is taken from Populstat (http://www.populstat.info/). 


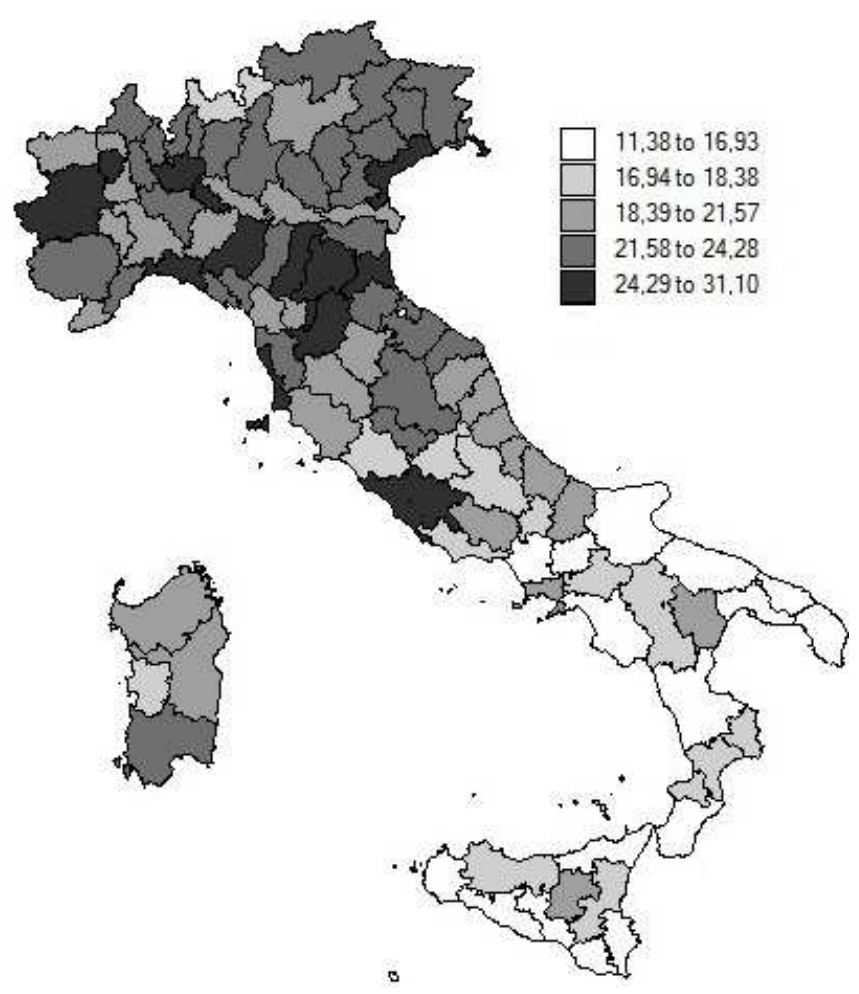

Figure 1: Average PSI across provinces (in level).

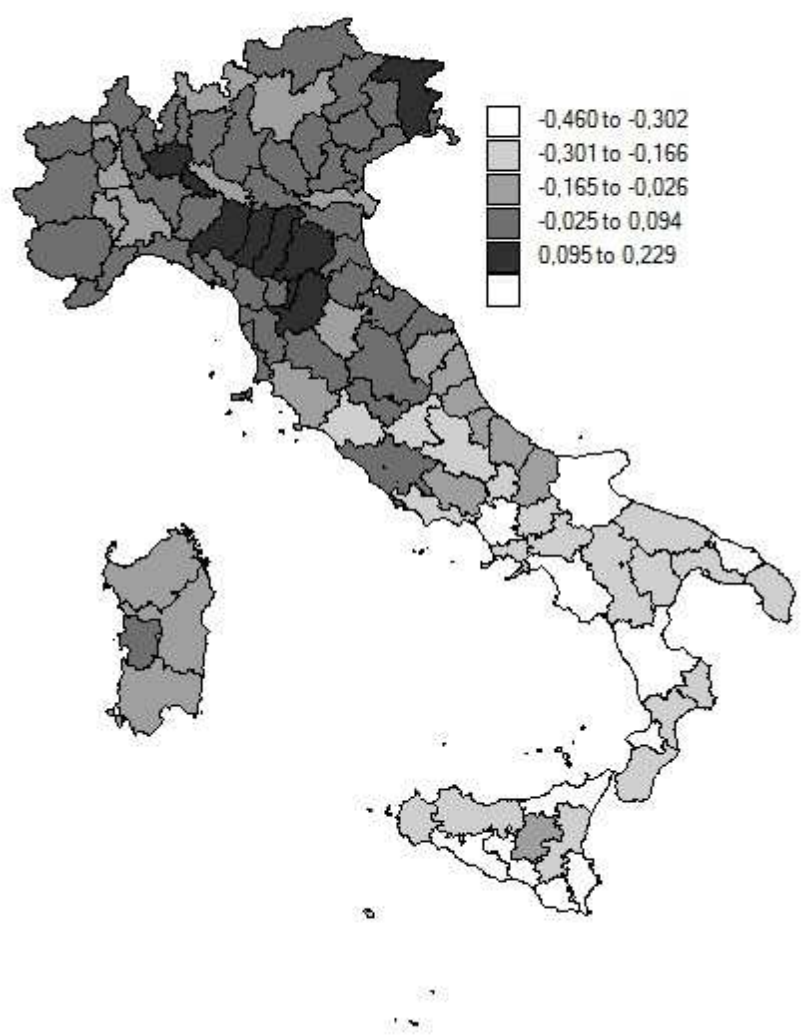

Figure 2: The figure plots the provincial average of firm-level residuals of a regression of PSI on 3-digit industry dummies. 


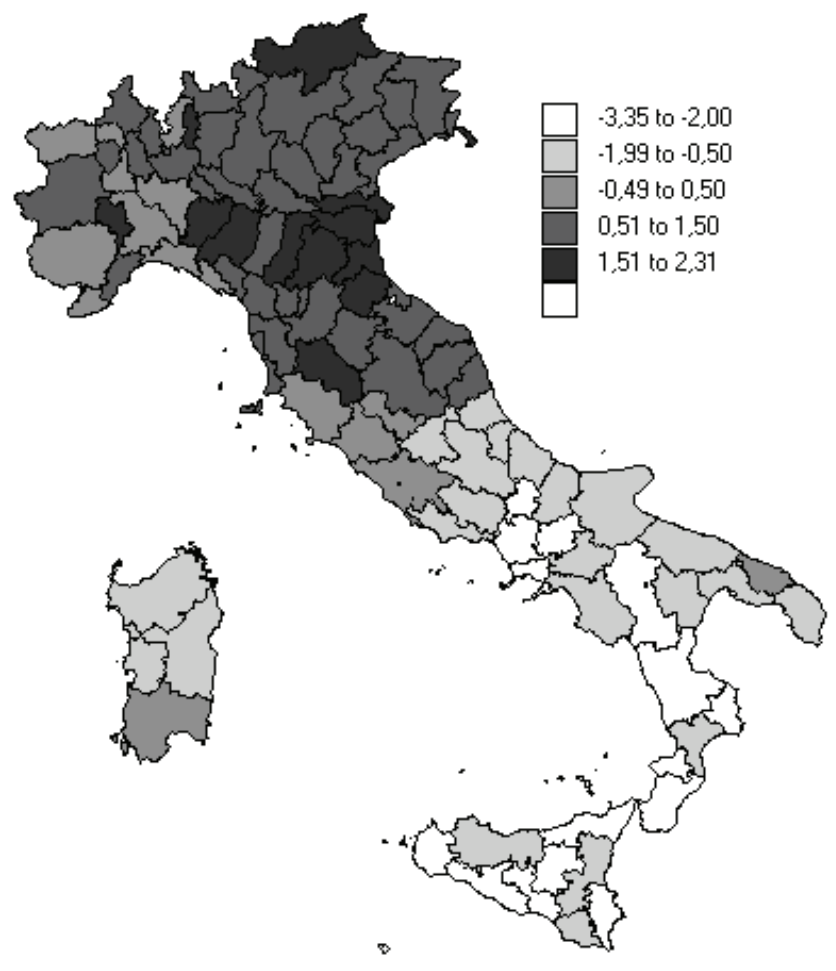

Figure 3: Map of civic capital measured by the first principal component of blood donations, volunteering, and electoral turnout. 
Table 1: Descriptive statistics

\begin{tabular}{|c|c|c|c|c|c|c|c|c|}
\hline Variable & Obs. & Mean & S.D. & Min & Max & 1st Quartile & Median & 3rd Quartile \\
\hline \multicolumn{9}{|l|}{ Firm-level variables } \\
\hline PSI (log) & 877,736 & 2.91 & 0.94 & -8.16 & 6.08 & 2.34 & 3.00 & 3.55 \\
\hline Employees (log) & 877,736 & 2.18 & 1.35 & 0 & 12.20 & 1.10 & 2.08 & 3.04 \\
\hline Capital (log) & 877,736 & 11.91 & 2.12 & 0 & 23.82 & 10.50 & 11.84 & 13.35 \\
\hline Firm age (log) & 877,736 & 2.37 & 0.95 & 0 & 6.81 & 1.79 & 2.48 & 3.09 \\
\hline Value added / Sales (log) & 858,371 & 3.11 & 0.82 & -10.40 & 5.52 & 2.64 & 3.21 & 3.68 \\
\hline \multicolumn{9}{|l|}{ Civic capital variables } \\
\hline Referenda turnout (log) & 103 & 4.39 & 0.11 & 4.13 & 4.52 & 4.30 & 4.42 & 4.47 \\
\hline Blood donations (log) & 103 & 3.57 & 0.42 & 2.50 & 4.44 & 3.26 & 3.64 & 3.84 \\
\hline Volunteers (log) & 103 & 8.53 & 0.63 & 7.10 & 10.01 & 8.15 & 8.60 & 8.93 \\
\hline Principal component & 103 & 0 & 1.5 & -3.35 & 2.31 & -1.23 & 0.44 & 1.13 \\
\hline \multicolumn{9}{|l|}{ Historical variables } \\
\hline Aid societies in $1873(\log )$ & 20 & 4.03 & 0.09 & 3.82 & 4.21 & 3.97 & 4.03 & 4.08 \\
\hline Turnout in 1920s $(\log )$ & 20 & 6.25 & 0.98 & 4.16 & 7.47 & 5.41 & 6.54 & 7.07 \\
\hline Number of free-city states & 67 & 0.85 & 0.78 & 0 & 3 & 0 & 1 & 1 \\
\hline \multicolumn{9}{|l|}{ Other explanatory variables } \\
\hline Service workers $(\log )$ & 721 & 10.75 & 0.86 & 8.79 & 14.03 & 10.18 & 10.66 & 11.18 \\
\hline Total workers $(\log )$ & 721 & 12.04 & 0.74 & 10.42 & 14.54 & 11.57 & 11.94 & 12.44 \\
\hline University graduates $(\log )$ & 103 & 1.85 & 0.18 & 1.46 & 2.45 & 1.73 & 1.85 & 1.93 \\
\hline Bank branches (log) & 103 & 1.59 & 0.44 & -0.66 & 2.33 & 1.27 & 1.72 & 1.91 \\
\hline Length of trials $(\log )$ & 103 & 6.94 & 0.34 & 6.19 & 7.72 & 6.72 & 6.92 & 7.18 \\
\hline GDP $(\log )$ & 103 & 15.79 & 0.80 & 14.05 & 18.57 & 15.23 & 15.71 & 16.24 \\
\hline
\end{tabular}

Note: The table provides descriptive statistics for the variables used in the regressions. The dependent variable, PSI (log), is the log of purchased service intensity, defined as the amount spent on external service provision divided by sales. Employees (log) is the log of the number of employees. Capital (log) is the log of the firms' capital stock, defined as total tangible fixed assets. Firm age (log) is the log of the firm age. Value added / Sales (log) is the log of firm value added divided by sales. All firm level variables are taken from AIDA and refer to the years from 2001 to 2007 . We consider the following variables to measure civic capital: Referenda turnout is the log of the average electoral turnout in referenda between 1946 and 1987; Blood donations is the log of the number of blood donations per 100,000 inhabitants in 2002; Volunteers is the log of the number of volunteers in non-profit institutions per 100,000 inhabitants in 2000; Principal component is the first principal component of the above mentioned three proxies of civic capital. The historical instruments are: Turnout in 1920s is the the log of turnout in the elections that took place in Italy in the 1920s; Aid societies in 1873 is the log of the members of mutual aid societies per 100,000 inhabitants in 1873; Number of free-city states is the number of free-city states in the territory of each province in 1300. The provincial controls are the following: Service workers $(\log )$ is the log of total service workers in a given province (NACE rev 1.1 two digit industries 50-74) Total workers (log) is the log of all workers in a given province (full-time equivalent of workers hired in every sector); University graduates is the log of the share of university graduates over total population; Bank branches is the log of the number of bank branches per 1000 inhabitants; Length of trials is the log of the number of days it takes to complete a first-degree trial in civil affairs; GDP $(\log )$ is the $\log$ of the provincial nominal gross domestic product. 
Table 2: Baseline regressions

\begin{tabular}{|c|c|c|c|c|c|c|c|c|}
\hline & \multicolumn{6}{|c|}{ Pooled OLS } & \multicolumn{2}{|c|}{ GMM } \\
\hline & (1) & $(2)$ & (3) & (4) & (5) & (6) & (7) & \\
\hline & Coef./se & Coef./se & Coef./se & Coef./se & Coef./se & Coef./se & Coef./se & Coef./se \\
\hline Referenda turnout $(\log )$ & $\begin{array}{c}0.529^{* * *} \\
(0.140)\end{array}$ & & & & $\begin{array}{r}0.098^{* *} \\
(0.038)\end{array}$ & & $\begin{array}{r}0.284^{* * *} \\
(0.091)\end{array}$ & \\
\hline Blood donations $(\log )$ & & $\begin{array}{r}0.008 \\
(0.020)\end{array}$ & & & & & & \\
\hline Volunteers (log) & & & $\begin{array}{r}0.015 \\
(0.016)\end{array}$ & & & & & \\
\hline Principal component & & & & $\begin{array}{r}0.023^{* *} \\
(0.010)\end{array}$ & & $\begin{array}{r}0.008^{* * *} \\
(0.002)\end{array}$ & & $\begin{array}{r}0.022^{* * * *} \\
(0.007)\end{array}$ \\
\hline Employees $(\log )$ & $\begin{array}{r}-0.051^{* * *} \\
(0.003)\end{array}$ & $\begin{array}{r}-0.051^{* * *} \\
(0.003)\end{array}$ & $\begin{array}{r}-0.051^{* * *} \\
(0.003)\end{array}$ & $\begin{array}{r}-0.051^{* * *} \\
(0.003)\end{array}$ & $\begin{array}{r}-0.011^{* * *} \\
(0.001)\end{array}$ & $\begin{array}{r}-0.011^{* * * *} \\
(0.001)\end{array}$ & $\begin{array}{r}-0.088^{* * *} \\
(0.007)\end{array}$ & $\begin{array}{r}-0.089^{* * *} \\
(0.007)\end{array}$ \\
\hline Capital (log) & $\begin{array}{r}0.037^{* * *} \\
(0.004)\end{array}$ & $\begin{array}{r}0.036^{* * *} \\
(0.004)\end{array}$ & $\begin{array}{r}0.036^{* * *} \\
(0.004)\end{array}$ & $\begin{array}{r}0.036^{* * *} \\
(0.004)\end{array}$ & $\begin{array}{r}0.008^{* * *} \\
(0.001)\end{array}$ & $\begin{array}{r}0.008^{* * *} \\
(0.001)\end{array}$ & $\begin{array}{r}0.011^{* * *} \\
(0.004)\end{array}$ & $\begin{array}{r}0.011^{* * *} \\
(0.004)\end{array}$ \\
\hline Firm age $(\log )$ & $\begin{array}{r}-0.008^{* * *} \\
(0.003)\end{array}$ & $\begin{array}{r}-0.007^{* * *} \\
(0.003)\end{array}$ & $\begin{array}{r}-0.007^{* * *} \\
(0.003)\end{array}$ & $\begin{array}{r}-0.007^{* * *} \\
(0.003)\end{array}$ & $\begin{array}{r}0.003^{* *} \\
(0.001)\end{array}$ & $\begin{array}{r}0.003^{* *} \\
(0.001)\end{array}$ & $\begin{array}{r}0.033^{* * *} \\
(0.004)\end{array}$ & $\begin{array}{r}0.033^{* * *} \\
(0.004)\end{array}$ \\
\hline Service workers $(\log )$ & $\begin{array}{r}0.047^{* * *} \\
(0.007)\end{array}$ & $\begin{array}{r}0.041^{* * *} \\
(0.007)\end{array}$ & $\begin{array}{r}0.041^{* * *} \\
(0.007)\end{array}$ & $\begin{array}{r}0.042^{* * *} \\
(0.007)\end{array}$ & $\begin{array}{r}0.009^{* * * *} \\
(0.002)\end{array}$ & $\begin{array}{r}0.008^{* * * *} \\
(0.002)\end{array}$ & $\begin{array}{r}0.008^{* *} \\
(0.004)\end{array}$ & $\begin{array}{r}0.010^{* * * *} \\
(0.004)\end{array}$ \\
\hline Length of trials $(\log )$ & $\begin{array}{r}-0.000 \\
(0.021)\end{array}$ & $\begin{array}{r}0.012 \\
(0.020)\end{array}$ & $\begin{array}{r}0.011 \\
(0.021)\end{array}$ & $\begin{array}{r}0.007 \\
(0.021)\end{array}$ & $\begin{array}{r}0.001 \\
(0.005)\end{array}$ & $\begin{array}{r}0.002 \\
(0.004)\end{array}$ & $\begin{array}{r}-0.034^{* * *} \\
(0.012)\end{array}$ & $\begin{array}{r}-0.028^{* * *} \\
(0.010)\end{array}$ \\
\hline Bank branches (log) & $\begin{array}{r}0.004 \\
(0.005)\end{array}$ & $\begin{array}{r}0.003 \\
(0.005)\end{array}$ & $\begin{array}{r}0.003 \\
(0.005)\end{array}$ & $\begin{array}{r}0.001 \\
(0.005)\end{array}$ & $\begin{array}{r}0.001 \\
(0.001)\end{array}$ & $\begin{array}{l}-0.001 \\
(0.001)\end{array}$ & $\begin{array}{r}0.001 \\
(0.007)\end{array}$ & $\begin{array}{c}-0.004 \\
(0.008)\end{array}$ \\
\hline University graduates $(\log )$ & $\begin{array}{r}-0.008 \\
(0.041)\end{array}$ & $\begin{array}{r}0.033 \\
(0.038)\end{array}$ & $\begin{array}{r}0.029 \\
(0.039)\end{array}$ & $\begin{array}{r}0.015 \\
(0.038)\end{array}$ & $\begin{array}{r}0.004 \\
(0.010)\end{array}$ & $\begin{array}{r}0.006 \\
(0.009)\end{array}$ & $\begin{array}{r}0.004 \\
(0.018)\end{array}$ & $\begin{array}{r}0.002 \\
(0.017)\end{array}$ \\
\hline $\mathrm{PSI}_{t-1}(\log )$ & & & & & $\begin{array}{r}0.753^{* * *} * \\
(0.008)\end{array}$ & $\begin{array}{r}0.753^{* * *} \\
(0.008)\end{array}$ & $\begin{array}{r}0.837^{* * *} * \\
(0.053)\end{array}$ & $\begin{array}{r}0.838^{* * *} \\
(0.054)\end{array}$ \\
\hline 3-dig & Yes & Yes & Yes & Yes & Yes & Yes & No & No \\
\hline Regional dummies & Yes & Yes & Yes & Yes & Yes & Yes & No & No \\
\hline$R^{2}$ & 0.355 & 0.355 & 0.355 & 0.355 & 0.768 & 0.768 & & \\
\hline Hansen $J$-test & & & & & & & 17.01 & 16.95 \\
\hline Hansen $p$-value & & & & & & & 0.11 & 0.11 \\
\hline Observations & 877,736 & 877,736 & 877,736 & 877,736 & 493,153 & 493,153 & 493,153 & 493,153 \\
\hline
\end{tabular}

Note: Standard errors are robust to arbitrary heteroskedasticity and corrected for clustering at the province level. $* * *, * *, *$ denote significance at the $1 \%, 5 \%, 10 \%$ level, respectively. We use the following variables to measure civic capital: Referenda turnout is the log of the average electoral turnout in referenda between 1946 and 1987; Blood donations is the log of the number of blood donations per 1000 inhabitants in 2002; Volunteers is the log of the number of volunteers in non-profit institutions per 100,000 inhabitants in 2000; Principal component is the first principal component of the above mentioned three proxies of civic capital. We include the following firm-level controls: Employees is the log of the total number of employees; Capital is the log of the firms' capital stock, defined as total tangible fixed assets; Firm age is the log of the firm age. We include the following provincial controls: Service workers is the log of total service workers in a given province (NACE rev 1.1 two digit industries 50-74); Length of trials is the log of the number of days it takes to complete a first-degree trial in labor-related affairs; Bank branches is the log of the number of bank branches per 1,000 inhabitants; University graduates is the log of the share of university graduates over total population. 
Table 3: Robustness checks

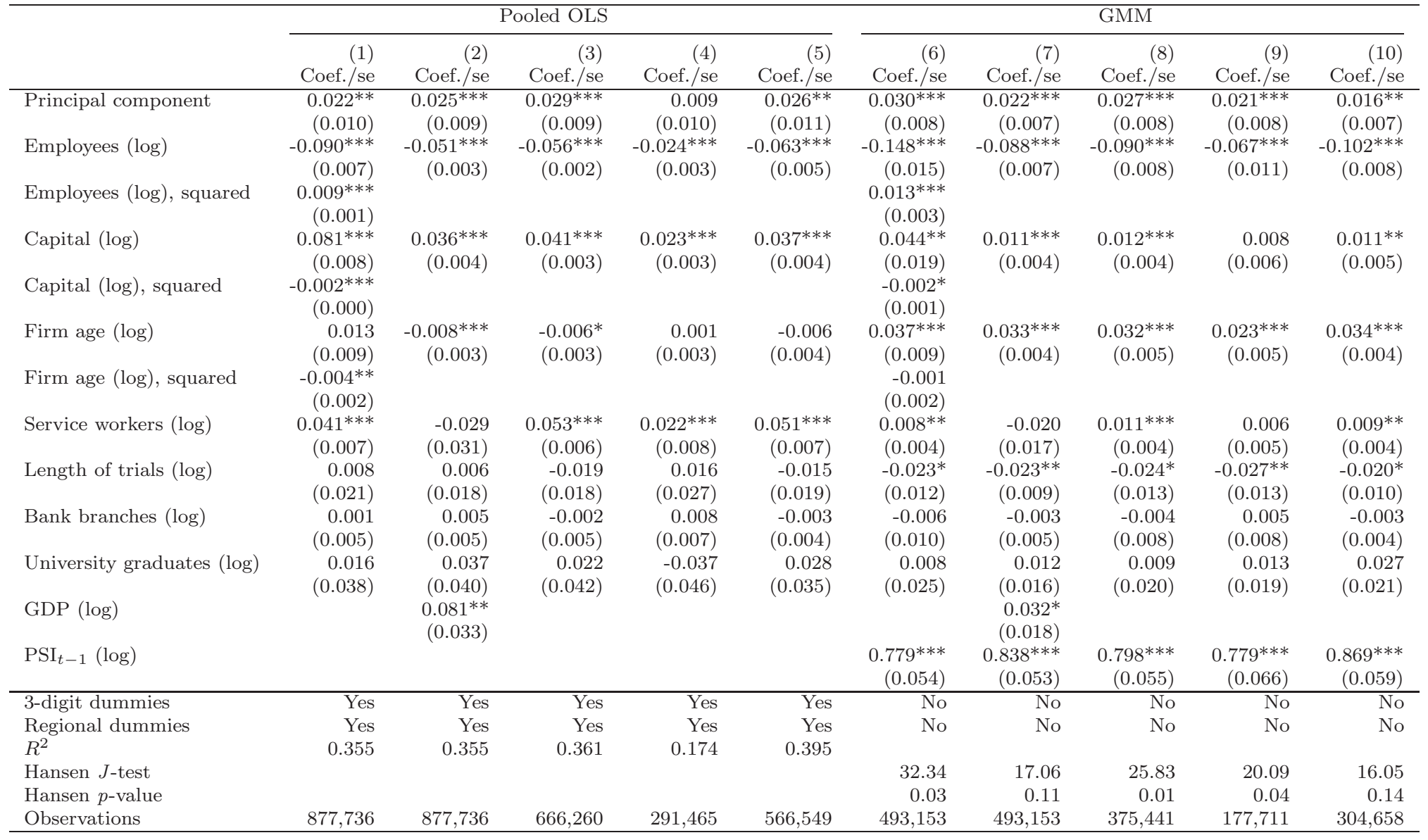

Note: Standard errors are robust to arbitrary heteroskedasticity and corrected for clustering at the province level. $* * *, * *, *$ denote significance at the 1\%,5\%,10\% level, respectively. To measure civic capital we use Principal component, the first principal component of the three proxies of civic capital. We include the following firm-level controls (both in levels and squared): Employees is the log of the total number of employees; Capital is the log of the firms' capital stock, defined as total tangible fixed assets; Firm age is the log of the firm age. We include the following provincial controls: Service workers is the log of total service workers in a given province (NACE rev 1.1 two digit industries 50-74); Length of trials is the log of the number of days it takes to complete a first-degree trial in labor-related affairs; Bank branches is the log of the number of bank branches per 1,000 inhabitants; University graduates is the log of the share of university graduates over total population; GDP is the log of the provincial nominal gross domestic product, expressed in thousands of euros. 
Table 4: Estimates with historical instruments

\begin{tabular}{|c|c|c|c|c|c|c|c|c|c|}
\hline \multicolumn{10}{|c|}{ Panel A: Second Stage (Dependent variable: Log of PSI) } \\
\hline & & $\begin{aligned}(2) \\
\text { OLS (no South) }\end{aligned}$ & $\begin{array}{r}(3) \\
\text { GMM (no South }\end{array}$ & $\begin{aligned}(4) \\
2 \mathrm{SLS}-1\end{aligned}$ & (5) & $(6)$ & $(7)$ & $(8)$ & (9) \\
\hline & Coef./se & $\begin{array}{l}\text { OLS (no South) } \\
\text { Coef./se }\end{array}$ & $\begin{array}{l}\text { GiMM (no South) } \\
\text { Coef./se }\end{array}$ & $\begin{array}{l}2 \text { SLS-1 } \\
\text { Coef./se }\end{array}$ & $\begin{array}{l}2 \mathrm{SLS}-2 \\
\text { Coef. } / \mathrm{se}\end{array}$ & $\begin{array}{l}2 \mathrm{SLSS3} \\
\text { Coef. } / \mathrm{se}\end{array}$ & $\begin{array}{l}\text { GMM } \\
\text { Coef./se }\end{array}$ & $\begin{array}{l}2 \text { SLS } \\
\text { Coef./se }\end{array}$ & $\begin{array}{l}\text { GMM } \\
\text { Coef/se }\end{array}$ \\
\hline Principal component & $0.063^{* * *}$ & $0.074^{* * * *}$ & $0.014^{* *}$ & $0.087^{* * *}$ & $0.073^{* * *}$ & $0.082^{* * *}$ & $0.023^{* *}$ & $0.077^{* * *}$ & $0.017^{* * *}$ \\
\hline & $(0.008)$ & $(0.012)$ & $(0.006)$ & $(0.016)$ & $(0.019)$ & $(0.016)$ & $(0.009)$ & $(0.018)$ & $(0.006)$ \\
\hline Size $(\log )$ & $\begin{array}{r}-0.051^{* * *} \\
(0.003)\end{array}$ & $\begin{array}{r}-0.050 * * * \\
(0.004)\end{array}$ & $\begin{aligned}-0.093 * * * \\
(0.008)\end{aligned}$ & $\begin{array}{r}-0.051^{* * *} \\
(0.003)\end{array}$ & $\begin{array}{r}-0.051^{* * * *} \\
(0.003)\end{array}$ & $\begin{array}{r}-0.051^{* * * *} \\
(0.003)\end{array}$ & $\begin{array}{r}-0.088^{* * *} * \\
(0.007)\end{array}$ & $\begin{array}{r}-0.050^{* * * *} \\
(0.004)\end{array}$ & $-0.092^{* * * *}$ \\
\hline Capital (log) & $0.036^{* * * *}$ & $0.027^{* * *}$ & 0.006 & $0.036^{* * *}$ & $0.036^{* * *}$ & $0.036^{* * * *}$ & $0.011^{* * *}$ & $0.027^{* * *}$ & $0.007^{*}$ \\
\hline & $(0.004)$ & $(0.003)$ & $(0.004)$ & $(0.004)$ & $(0.004)$ & $(0.004)$ & $(0.004)$ & $(0.003)$ & $(0.004)$ \\
\hline Firm age $(\log )$ & $\left.\begin{array}{rl}-0.007^{* *} \\
(0.003)\end{array}\right)$ & $\left.-0.013^{* * *}\right)$ & $\begin{array}{l}0.036^{* * *} \\
(0.004)\end{array}$ & $\begin{array}{l}-0.007^{* * *} \\
(0.003)\end{array}$ & $\begin{array}{r}-0.007^{* * *} \\
(0.003)\end{array}$ & $\begin{array}{r}-0.007^{* * * *} \\
(0.003)\end{array}$ & $\begin{array}{l}0.033^{* * *} \\
(0.004)\end{array}$ & $\begin{array}{r}-0.013^{* * *} \\
(0.002)\end{array}$ & $\begin{array}{l}0.036^{* * * *} \\
(0.004)\end{array}$ \\
\hline Province service workers $(\log )$ & $0.023^{* * * *}$ & $0.023^{* * * *}$ & $0.010^{* * *}$ & $0.028^{* * * *}$ & $0.028^{* * *}$ & $0.028^{* * *}$ & $0.012^{* * * *}$ & $0.025^{* * *}$ & $0.009^{* *}$ \\
\hline & $(0.006)$ & $(0.007)$ & $(0.004)$ & $(0.008)$ & $(0.008)$ & $(0.008)$ & $(0.005)$ & $(0.007)$ & $(0.004)$ \\
\hline Length of trials $(\log )$ & -0.044 & -0.018 & $-0.024^{* *}$ & -0.028 & -0.039 & -0.031 & $-0.023^{* *}$ & -0.015 & $-0.017^{* * * *}$ \\
\hline Bank branches $(\log )$ & $\begin{array}{r}(0.029) \\
0.000\end{array}$ & $\begin{array}{l}(0.031) \\
-0.004\end{array}-10$ & $\begin{array}{c}(0.010) \\
-0.004\end{array}$ & $\begin{array}{l}(0.030) \\
-0.009\end{array}-1$ & $\begin{array}{l}(0.034) \\
-0.004\end{array}$ & $\begin{array}{l}(0.031) \\
-0.008\end{array}$ & $\begin{array}{l}(0.010) \\
-0.006\end{array}$ & $\begin{array}{l}(0.031) \\
-0.005\end{array}$ & $\begin{aligned}(0.006) & -006 * * \\
-0.006 & -1\end{aligned}$ \\
\hline & $(0.009)$ & $(0.008)$ & $(0.003)$ & $(0.009)$ & $(0.010)$ & $(0.009)$ & $(0.006)$ & $(0.008)$ & $\begin{array}{r}-0.000 \\
(0.003)\end{array}$ \\
\hline University graduates $(\log )$ & 0.056 & 0.040 & -0.013 & 0.042 & 0.048 & 0.044 & 0.003 & 0.044 & -0.014 \\
\hline & $(0.044)$ & $(0.044)$ & $(0.017)$ & $(0.046)$ & $(0.044)$ & $(0.045)$ & $(0.015)$ & $(0.046)$ & $(0.013)$ \\
\hline Urbanization rate in $1861(\log )$ & & & & -0.006 & $\begin{array}{r}-0.009 \\
(0.009)\end{array}$ & -0.007 & $\begin{array}{l}-0.006 \\
(0.006)\end{array}$ & $\begin{array}{r}-0.009 \\
(0.010)\end{array}$ & -0.001 \\
\hline $\mathrm{PSI}_{t-1}$ & & & $0.815^{* * *}$ & & & & $0.840^{* * * *}$ & & $\begin{aligned} 0.853^{* * * *} \\
(0.052)\end{aligned}$ \\
\hline 3-digit dummies & Yes & Yes & No & Yes & Yes & Yes & No & Yes & No \\
\hline Macro-regional dummies & & & No & Yes & Yes & Yes & No & Yes & No \\
\hline Firm level covariates & Yes & Yes & Yes & Yes & Yes & Yes & Yes & Yes & Yes \\
\hline Province covariates & Yes & Yes & Yes & Yes & Yes & Yes & Yes & Yes & Yes \\
\hline$R^{2}$ & 0.354 & 0.336 & & 0.354 & 0.354 & 0.354 & & 0.337 & \\
\hline Obs. & 877,736 & 708,659 & 409,475 & 877,736 & 877,736 & 877,736 & 493,153 & 708,659 & 409,475 \\
\hline Hansen $J$-test & & & 14.41 & & & & 17.05 & & 14.80 \\
\hline Hansen $p$-value & & & 0.21 & & & & 0.15 & & 0.32 \\
\hline & & Panel B: First S & ge (Depend & ble: Princip & component & & & & \\
\hline Turnout $1920 \mathrm{~s}(\log )$ & & & & $5.488^{* * *}$ & & $4.155^{* * *}$ & & & \\
\hline Mutual aid societies (log) & & & & (1.000) & $1.059^{* * *}$ & $0.550^{* *}$ & & & \\
\hline 1 free-city in 1300 & & & & & & (0.258) & & $0.449^{* * *}$ & \\
\hline & & & & & & & & $\begin{array}{l}(0.146) \\
0.78 * * *\end{array}$ & \\
\hline 2 free-city in 1300 & & & & & & & & $\begin{array}{l}0.782^{2 * *} \\
(0.160)\end{array}$ & \\
\hline 3 free-city in 1300 & & & & & & & & -0.141 & \\
\hline & & & & & & & & $(0.221)$ & \\
\hline $\begin{array}{l}\text { F-stat of excluded instr. } \\
\text { F-stat } p \text {-value }\end{array}$ & & & & 30.10 & 24.08 & 16.97 & & 12.54 & \\
\hline $\begin{array}{l}\text { F-stat } p \text {-value } \\
\text { 3-digit dummie }\end{array}$ & & & & $\begin{array}{l}0.000 \\
\text { Yes }\end{array}$ & $\begin{aligned} 0.000 \\
\text { Yes }\end{aligned}$ & $\begin{array}{l}0.000 \\
\text { Yes }\end{array}$ & & $\begin{array}{c}0.000 \\
\text { Yes }\end{array}$ & \\
\hline $\begin{array}{l}\text { 3-digit dummies } \\
\text { Macro-regional dummies }\end{array}$ & & & & Yes & $\begin{array}{l}\text { Yes } \\
\text { Yes }\end{array}$ & Yes & & $\begin{array}{l}\text { Yes } \\
\text { Yes }\end{array}$ & \\
\hline Firm level covariates & & & & Yes & Yes & Yes & & Yes & \\
\hline Province covariates & & & & Yes & Yes & Yes & & Yes & \\
\hline Obs. & & & & 877,736 & 877,736 & 877,736 & & 708,659 & \\
\hline
\end{tabular}

Note: Standard errors are robust to arbitrary heteroskedasticity and corrected for clustering at the province level. $* * *, * * * *$ denote significance at the 1\%,5\%,10\% level, respectively. Panel A shows the second stage, while Panel B shows the first stage. In the first stage we use two sets of instrumental variables. The first set of instrumental variables are: Aid societies in 1873 is the log of the members of mutual aid societies per 100,000 inhabitants in 1873; Turnout in 1920s is the the log of turnout in the elections that took place in Italy in the 1920s. The second set of instrumental variables are dummies for the number of free-city states at the provincial level in 1300. 


\section{B Appendix with supplementary material}

This appendix contains some supplementary material for our paper.

\section{Robustness checks employing referendum turnout as main regres- sor}

In Tables $\mathrm{B}+1$ and $\mathrm{B}+2$ we replicate the robustness checks and the regressions with historical instruments employing referendum turnout as main regressor, instead of the principal component. The results are perfectly in line with those showed in the main text.

\section{Alternative measure of outsourcing as dependent variable}

According to our conceptual framework, civic capital should boost input outsourcing, thus leading to a reduction in the degree of vertical integration. In Table B+3 we present the estimates for pooled OLS and GMM regressions where the dependent variable is the logarithm of value added over sales. The regressors employed are the same of the baseline model, except the provincial control for the total number of workers, where we employ the full-time equivalent of the total number of workers hired by every sector, instead of the total number of workers hired by the service sector. This change is done because controlling only for local service workers would be less appropriate with value added over sales as dependent variable, since this is a more general measure that may be influenced by the availability of a wider array of inputs, not only services.

Results obtained replacing value added over sales as dependent are inconclusive. Our explanation for this is based on the fact that, according to equation (2), value added over sales is affected not only PSI, but also by PII (i.e. material inputs outsourcing) and by other types of external purchases. As we argued, in the case of material goods the location of the input seller is more uncertain, because he may well be located in another province or abroad, with the input being shipped to the buyer's address from a possibly distant place. When the buyer and the seller of the input do not share the same location, identifying the effect of civic capital on contractual hazards and the propensity to outsource is cumbersome. 
Table B1: Robustness checks with referendum turnout as main regressor

\begin{tabular}{|c|c|c|c|c|c|c|c|c|c|c|}
\hline & \multicolumn{5}{|c|}{ Pooled OLS } & \multicolumn{5}{|c|}{ GMM } \\
\hline & (1) & (2) & (3) & (4) & $\overline{(5)}$ & (6) & (7) & (8) & (9) & $(10)$ \\
\hline & Coef./se & Coef./se & Coef./se & Coef./se & Coef./se & Coef./se & Coef./se & Coef./se & Coef./se & Coef./se \\
\hline Referenda turnout (log) & $0.529^{* * *}$ & $0.529^{* * *}$ & $0.498^{* * *}$ & $0.622^{* * *}$ & $\begin{array}{r}0.446^{* * *} \\
(0.146)\end{array}$ & $0.384^{* * *}$ & $0.281^{* * *}$ & $0.352^{* * *}$ & $0.330^{* * *}$ & $0.194^{* *}$ \\
\hline Size (log) & $\begin{array}{r}-0.090^{* * *} \\
(0.007)\end{array}$ & $\begin{array}{r}-0.051^{* * *} \\
(0.003)\end{array}$ & $\begin{array}{r}-0.056^{* * *} \\
(0.002)\end{array}$ & $\begin{array}{r}-0.023^{* * *} \\
(0.003)\end{array}$ & $\begin{array}{r}-0.063^{* * *} \\
(0.005)\end{array}$ & $\begin{array}{r}-0.148^{* * *} \\
(0.015)\end{array}$ & $\begin{array}{r}-0.088^{* * *} \\
(0.007)\end{array}$ & $\begin{array}{r}-0.090^{* * *} \\
(0.008)\end{array}$ & $\begin{array}{r}-0.067^{* * *} \\
(0.010)\end{array}$ & $\begin{array}{r}-0.102^{* * *} \\
(0.008)\end{array}$ \\
\hline Size (log), squared & $\begin{array}{r}0.009^{* * *} \\
(0.001)\end{array}$ & & & & & $\begin{array}{r}0.013^{* * *} \\
(0.003)\end{array}$ & & & & \\
\hline Capital (log) & $\begin{array}{r}0.081^{* * *} \\
(0.008)\end{array}$ & $\begin{array}{r}0.036^{* * *} \\
(0.004)\end{array}$ & $\begin{array}{r}0.041^{* * *} \\
(0.003)\end{array}$ & $\begin{array}{r}0.023^{* * *} \\
(0.003)\end{array}$ & $\begin{array}{r}0.037^{* * *} \\
(0.004)\end{array}$ & $\begin{array}{r}0.045^{* *} \\
(0.019)\end{array}$ & $\begin{array}{r}0.011^{* * * *} \\
(0.004)\end{array}$ & $\begin{array}{r}0.012^{* * * *} \\
(0.004)\end{array}$ & $\begin{array}{r}0.008 \\
(0.006)\end{array}$ & $\begin{array}{r}0.011^{* *} \\
(0.005)\end{array}$ \\
\hline Capital (log), squared & $\begin{array}{r}-0.002^{* * *} \\
(0.000)\end{array}$ & & & & & $\begin{array}{c}-0.002^{*} \\
(0.001)\end{array}$ & & & & \\
\hline Firm age (log) & $\begin{array}{r}0.013 \\
(0.009)\end{array}$ & $\begin{array}{r}-0.008^{* * *}(0.003)\end{array}$ & $\begin{array}{c}-0.006^{*} \\
(0.003)\end{array}$ & $\begin{array}{r}0.000 \\
(0.003)\end{array}$ & $\begin{array}{r}-0.006 \\
(0.004)\end{array}$ & $\begin{array}{r}0.037^{* * *} \\
(0.009)\end{array}$ & $\begin{array}{r}0.033^{* * *} \\
(0.004)\end{array}$ & $\begin{array}{r}0.032^{* * *} \\
(0.005)\end{array}$ & $\begin{array}{r}0.023^{* * *} \\
(0.005)\end{array}$ & $\begin{array}{r}0.034^{* * *} \\
(0.004)\end{array}$ \\
\hline Firm age (log), squared & $\begin{array}{r}-0.004^{* *} \\
(0.002)\end{array}$ & & & & & $\begin{array}{r}-0.001 \\
(0.002)\end{array}$ & & & & \\
\hline Province service workers $(\log )$ & $\begin{array}{r}0.047^{* * *} \\
(0.007)\end{array}$ & $\begin{array}{r}-0.016 \\
(0.031)\end{array}$ & $\begin{array}{r}0.056 * * * \\
(0.007)\end{array}$ & $\begin{array}{r}0.029 * * * \\
(0.008)\end{array}$ & $\begin{array}{r}0.056 * * * \\
(0.007)\end{array}$ & $\begin{array}{l}0.007^{*} \\
(0.004)\end{array}$ & $\begin{array}{l}-0.006 \\
(0.016)\end{array}$ & $\begin{array}{r}0.010^{* *} \\
(0.005)\end{array}$ & $\begin{array}{r}0.004 \\
(0.005)\end{array}$ & $\begin{array}{c}0.008^{*} \\
(0.005)\end{array}$ \\
\hline Length of trials (log) & $\begin{array}{r}-0.000 \\
(0.021)\end{array}$ & $\begin{array}{r}-0.001 \\
(0.019)\end{array}$ & $\begin{array}{r}-0.021 \\
(0.020)\end{array}$ & $\begin{array}{r}0.002 \\
(0.027)\end{array}$ & $\begin{array}{r}-0.018 \\
(0.020)\end{array}$ & $\begin{array}{r}-0.036^{* * *} \\
(0.014)\end{array}$ & $\begin{array}{r}-0.032^{* * *} \\
(0.012)\end{array}$ & $\begin{array}{r}-0.028^{* *} \\
(0.014)\end{array}$ & $\begin{array}{r}-0.029 * * * \\
(0.011)\end{array}$ & $\begin{array}{c}-0.028^{*} \\
(0.015)\end{array}$ \\
\hline Bank branches (log) & $\begin{array}{r}0.004 \\
(0.005)\end{array}$ & $\begin{array}{r}0.007 \\
(0.005)\end{array}$ & $\begin{array}{r}0.002 \\
(0.004)\end{array}$ & $\begin{array}{r}0.009 \\
(0.007)\end{array}$ & $\begin{array}{r}0.000 \\
(0.004)\end{array}$ & $\begin{array}{r}0.001 \\
(0.009)\end{array}$ & $\begin{array}{r}0.001 \\
(0.007)\end{array}$ & $\begin{array}{r}0.003 \\
(0.008)\end{array}$ & $\begin{array}{r}0.007 \\
(0.008)\end{array}$ & $\begin{array}{r}-0.000 \\
(0.006)\end{array}$ \\
\hline University graduates (log) & $\begin{array}{r}-0.008 \\
(0.041)\end{array}$ & $\begin{array}{r}0.012 \\
(0.043)\end{array}$ & $\begin{array}{r}0.003 \\
(0.044)\end{array}$ & $\begin{array}{r}-0.075 \\
(0.049)\end{array}$ & $\begin{array}{r}0.011 \\
(0.038)\end{array}$ & $\begin{array}{r}0.009 \\
(0.026)\end{array}$ & $\begin{array}{r}0.009 \\
(0.019)\end{array}$ & $\begin{array}{r}0.016 \\
(0.021)\end{array}$ & $\begin{array}{r}0.018 \\
(0.018)\end{array}$ & $\begin{array}{r}0.029 \\
(0.022)\end{array}$ \\
\hline GDP (log) & & $\begin{array}{r}0.072^{* *} \\
(0.033)\end{array}$ & & & & & $\begin{array}{r}0.015 \\
(0.015)\end{array}$ & & & \\
\hline $\mathrm{PSI}_{t-1}(\log )$ & & & & & & $\begin{array}{r}0.778^{* * *} \\
(0.054)\end{array}$ & $\begin{array}{r}0.837 * * * \\
(0.053)\end{array}$ & $\begin{array}{r}0.798^{* * * *} \\
(0.055)\end{array}$ & $\begin{array}{r}0.772^{* * *} \\
(0.068)\end{array}$ & $\begin{array}{r}0.867^{* * *} \\
(0.059)\end{array}$ \\
\hline 3-digit dummies & Yes & Yes & Yes & Yes & Yes & No & No & No & No & No \\
\hline Regional dummies & Yes & Yes & Yes & Yes & Yes & No & No & No & No & No \\
\hline$R^{2}$ & 0.356 & 0.355 & 0.361 & 0.174 & 0.395 & & & & & \\
\hline Hansen $J$-test & & & & & & 32.55 & 17.05 & 25.81 & 20.09 & 16.05 \\
\hline Hansen $p$-value & & & & & & 0.03 & 0.11 & 0.01 & 0.04 & 0.14 \\
\hline Observations & 877,736 & 877,736 & 666,260 & 291,465 & 566,549 & 493,153 & 493,153 & 375,441 & 177,711 & 304,658 \\
\hline
\end{tabular}

Note: Standard errors are robust to arbitrary heteroskedasticity and corrected for clustering at the province level. $* * *, * *, *$ denote significance at the 1\%,5\%,10\% level, respectively. To measure civic capital we use Referendum turnout, the log of the average electoral turnout in referenda between 1946 and 1987. We include the following firm-level controls: Employees is the log of the total number of employees; Capital is the log of the firms' capital stock, defined as total tangible fixed assets; Firm age is the log of the firm age. We include the following provincial controls: Service workers is the log of total service workers in a given province (NACE rev 1.1 two digit industries 50-74); Length of trials is the log of the number of days it takes to complete a first-degree trial in labor-related affairs; Bank branches is the log of the number of bank branches per 1,000 inhabitants; University graduates is the log of the share of university graduates over total population; GDP is the log of the provincial nominal gross domestic product, expressed in thousands of euros. 
Table B 2: Estimates with historical instruments and referendum turnout as main regressor

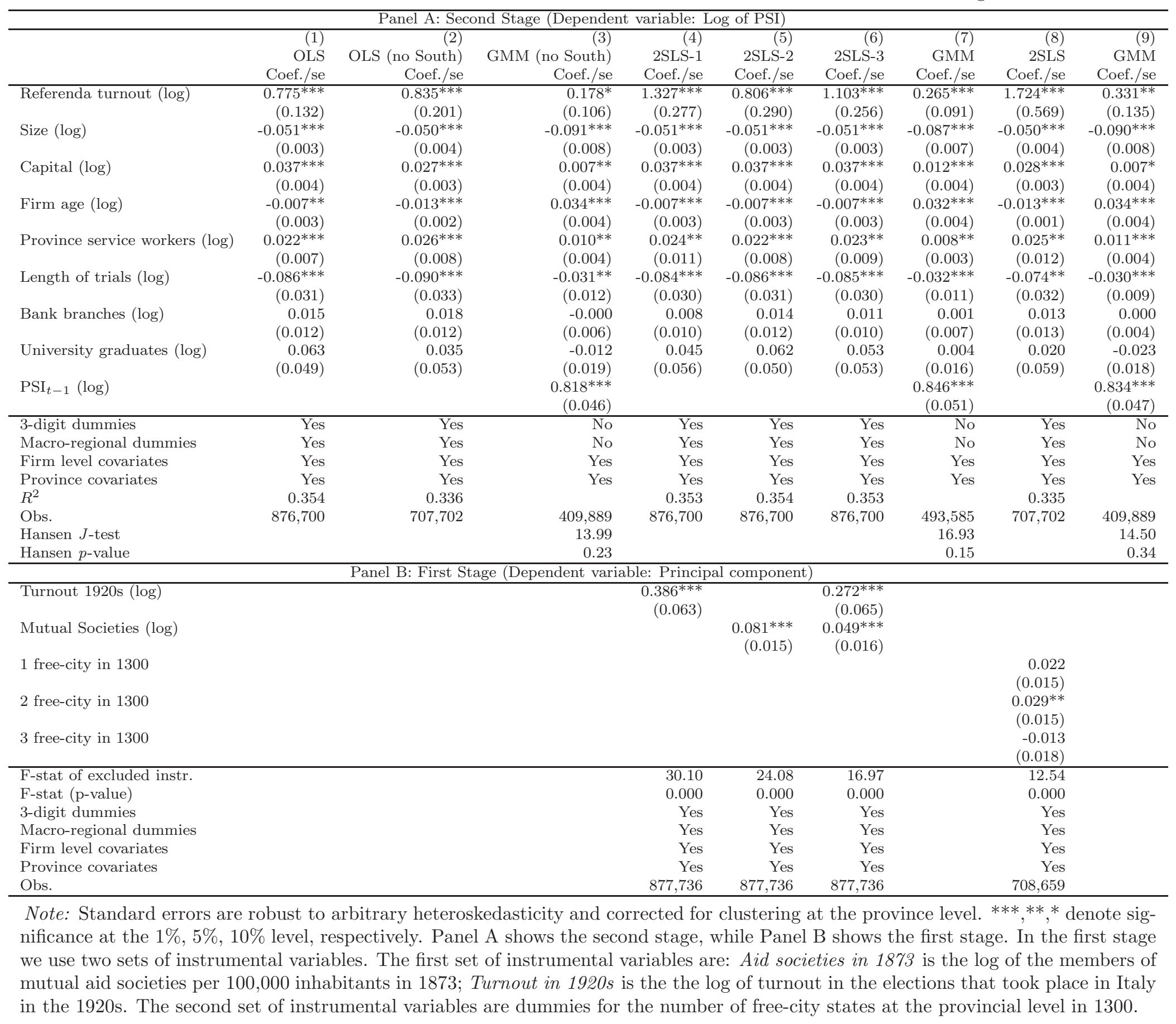


Table B-3: Value added over sales as dependent variable

\begin{tabular}{|c|c|c|c|c|}
\hline & \multicolumn{2}{|c|}{ Pooled OLS } & \multicolumn{2}{|c|}{ GMM } \\
\hline & (1) & (2) & (3) & (4) \\
\hline & Coef./se & Coef./se & Coef./se & Coef./se \\
\hline \multirow[t]{2}{*}{ Referenda turnout (log) } & 0.191 & & -0.106 & \\
\hline & $(0.138)$ & & $(0.125)$ & \\
\hline \multirow[t]{2}{*}{ Principal component } & & 0.011 & & -0.000 \\
\hline & & $(0.007)$ & & $(0.009)$ \\
\hline \multirow[t]{2}{*}{ Employees (log) } & $0.107^{* * *}$ & $0.107^{* * *}$ & $0.036^{* * *}$ & $0.037^{* * *}$ \\
\hline & $(0.003)$ & $(0.003)$ & $(0.009)$ & $(0.009)$ \\
\hline \multirow[t]{2}{*}{ Capital (log) } & $0.005^{* * *}$ & $0.005^{* * *}$ & $-0.009^{*}$ & $-0.009^{*}$ \\
\hline & $(0.001)$ & $(0.001)$ & $(0.005)$ & $(0.005)$ \\
\hline \multirow[t]{2}{*}{ Firm age $(\log )$} & $0.026^{* * *}$ & $0.026^{* * *}$ & $0.017 * *$ & $0.016^{* *}$ \\
\hline & $(0.005)$ & $(0.005)$ & $(0.007)$ & $(0.007)$ \\
\hline \multirow{2}{*}{ Total workers $(\log )$} & $-0.042^{* * *}$ & $-0.044^{* * *}$ & -0.010 & -0.010 \\
\hline & $(0.008)$ & $(0.007)$ & $(0.011)$ & $(0.010)$ \\
\hline \multirow[t]{2}{*}{ Length of trials (log) } & -0.029 & -0.027 & -0.044 & -0.034 \\
\hline & $(0.023)$ & $(0.022)$ & $(0.027)$ & $(0.029)$ \\
\hline \multirow[t]{2}{*}{ Bank branches (log) } & $-0.018^{* *}$ & $-0.019 * *$ & -0.023 & -0.029 \\
\hline & $(0.007)$ & $(0.008)$ & $(0.022)$ & $(0.029)$ \\
\hline \multirow[t]{2}{*}{ University graduates (log) } & $0.105^{* * *}$ & $0.110^{* * *}$ & 0.045 & 0.041 \\
\hline & $(0.035)$ & $(0.032)$ & $(0.043)$ & $(0.043)$ \\
\hline \multirow[t]{2}{*}{ VA over sales ${ }_{t-1}(\log )$} & & & $0.411^{* * *}$ & $0.412^{* * *}$ \\
\hline & & & $(0.024)$ & $(0.024)$ \\
\hline 3-digit dummies & Yes & Yes & No & No \\
\hline Regional dummies & Yes & Yes & No & No \\
\hline$R^{2}$ & 0.335 & 0.335 & & \\
\hline Observations & 858,371 & 858,371 & 480,979 & 480,979 \\
\hline Hansen $J$-test & & & 53.49 & 53.84 \\
\hline Hansen $p$-value & & & 0.00 & 0.00 \\
\hline
\end{tabular}

Note: Standard errors are robust to arbitrary heteroskedasticity and corrected for clustering at the province level. $* * *, * *, *$ denote significance at the $1 \%, 5 \%, 10 \%$ level, respectively. We use the following variables to measure civic capital: Referenda turnout is the log of the average electoral turnout in referenda between 1946 and 1987; Principal component is the first principal component of the three proxies of civic capital. We include the following firm-level controls: Employees is the log of the total number of employees; Capital is the log of the firms' capital stock, defined as total tangible fixed assets; Firm age is the log of the firm age. We include the following provincial controls: Total workers is the log of the total number of workers in a given province; Length of trials is the log of the number of days it takes to complete a first-degree trial in laborrelated affairs; Bank branches is the log of the number of bank branches per 1,000 inhabitants; University graduates is the log of the share of university graduates over total population. 


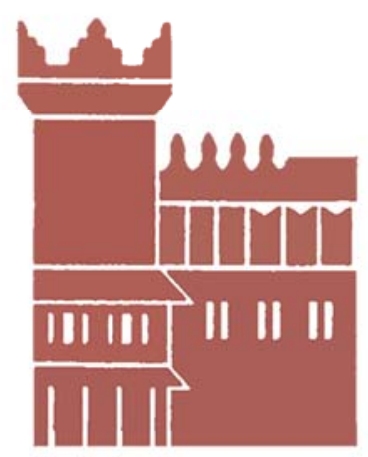

Alma Mater Studiorum - Università di Bologna DEPARTMENT OF ECONOMICS

Strada Maggiore 45

40125 Bologna - Italy

Tel. +39051 2092604

Fax +390512092664

http://www.dse.unibo.it 